IZA DP No. 8520

In Transit: The Well-Being of Migrants from Transition and Post-Transition Countries

Milena Nikolova

Carol Graham

October 2014 


\title{
In Transit: The Well-Being of Migrants from Transition and Post-Transition Countries
}

\author{
Milena Nikolova \\ IZA and Brookings Institution \\ Carol Graham \\ Brookings Institution, \\ University of Maryland and IZA
}

\section{Discussion Paper No. 8520 \\ October 2014}

\author{
IZA \\ P.O. Box 7240 \\ 53072 Bonn \\ Germany \\ Phone: +49-228-3894-0 \\ Fax: +49-228-3894-180 \\ E-mail: iza@iza.org
}

\begin{abstract}
Any opinions expressed here are those of the author(s) and not those of IZA. Research published in this series may include views on policy, but the institute itself takes no institutional policy positions. The IZA research network is committed to the IZA Guiding Principles of Research Integrity.

The Institute for the Study of Labor (IZA) in Bonn is a local and virtual international research center and a place of communication between science, politics and business. IZA is an independent nonprofit organization supported by Deutsche Post Foundation. The center is associated with the University of Bonn and offers a stimulating research environment through its international network, workshops and conferences, data service, project support, research visits and doctoral program. IZA engages in (i) original and internationally competitive research in all fields of labor economics, (ii) development of policy concepts, and (iii) dissemination of research results and concepts to the interested public.
\end{abstract}

IZA Discussion Papers often represent preliminary work and are circulated to encourage discussion. Citation of such a paper should account for its provisional character. A revised version may be available directly from the author. 
IZA Discussion Paper No. 8520

October 2014

\section{ABSTRACT \\ In Transit: The Well-Being of Migrants from Transition and Post-Transition Countries}

The extant literature has focused on migration's consequences for the receiving countries. In this paper, we ask a different but important question: how much do migrants gain from moving to another country? Using Gallup World Poll data and a methodology combining statistical matching with difference-in-differences, we assess migration's effects on the wellbeing of migrants from transition economies. We contribute to the literature by showing that in addition to increasing household income, migration enhances subjective well-being and satisfaction with freedom. The results are robust to sensitivity checks. Understanding the causal effects of migration on perceived and actual well-being is crucial for an informed public policy debate and has direct implications for social cohesion and integration policy.

JEL Classification: F22, I31, J61, O15

Keywords: migration, transition economies, subjective well-being

Corresponding author:

Milena Nikolova

IZA

P.O. Box 7240

53072 Bonn

Germany

E-mail: Nikolova@iza.org 


\section{Introduction}

The recent economic crisis not only increased the demand for social protection but also revived the immigration debate by emphasizing the distributional consequences of immigration on natives in advanced economies. ${ }^{1}$ In this study, we address a related but under-studied question: do the migrants gain from moving to another country? About three percent of the world's population lives outside its country of birth and most migrants move from developing to advanced societies, both to maximize their earnings and achieve a better quality of life (Hanson, 2010; Stillman, Gibson, McKenzie, \& Rohorua, 2015). While migrants improve their material well-being in destination countries (Abramitzky, Boustan, \& Eriksson, 2012; Clemens, Montenegro, \& Pritchett, 2008; McKenzie, Stillman, \& Gibson, 2010), the cross-sectional evidence on the effects of migration on subjective well-being (SWB) and quality of life is ambiguous. For example, while the majority of studies find that migration is associated with unhappiness (Simpson, 2014), immigrants from Western Europe are happier than those from the former Soviet countries in Israel (Amit, 2010; Amit \& Litwin, 2010). In another study, Bartram (2013) finds that movers from Central and Eastern Europe have the same happiness levels as stayers, although migrants form Russia, Turkey, and Romania are happier, and Polish migrants are unhappier than stayers.

While existing studies have looked at the happiness consequences of migration, most of them rely on cross-sectional data and simple OLS frameworks, which fail to deal with endogeneity (Simpson, 2014). Ideally, we would like to have a dataset tracing international migrants before and after the move and allowing us compare the very same migrants with similar

\footnotetext{
${ }^{1}$ See De Haas (2010) for a historical perspective of the immigration debate and Grether et al. (2001) for a political economy perspective on immigration. Following the policy discourse, labor economists have investigated immigration's economic and fiscal consequences for the host countries (Blanchflower \& Shadforth, 2009; Borjas, 1994, 2001; Card, 2005; Dustmann, Frattini, \& Halls, 2010; Ottaviano \& Peri, 2012) while development scholars have studied immigration's effects on development in sending countries (Bhagwati \& Hamada, 1974; Stark \& Wang, 2002).
} 
individuals before and after. In the absence of an experiment and panel data tracing international migrants and stayers before and after migration, we rely on statistical techniques in order to retrieve the causal effect of migration or at least mitigate biases coming from observational data. In particular, we employ an empirical approach combining statistical matching and difference-indifferences (DID) to explore the consequences of migration on movers' incomes, subjective well-being, and freedom satisfaction.

Our main results show that migration improves the incomes, life satisfaction, and the satisfaction with freedom of movers from transition economies. The average household earnings gain from migration is about 21,000 international dollars (ID), while the mean life satisfaction benefit is about 1.0 -1.2 on a scale of $0-10$. Migration also positively affects perceptions of freedom, implying that it presents new opportunities and choices for movers from transition economies. While our results can in principle be interpreted as causal, readers should exert caution when doing so. Being non-experimental, our empirical strategy is subject to several biases and limitations, discussed in Section 8 .

We study migrants from transition and post-transition societies as they are quantitatively the most significant migration source for the European OECD countries (OECD, 2007) and are key sources of high-skilled migrants for advanced economies in general. ${ }^{2,3}$ For example, Poland and Romania were among the top three sources of OECD migrants in 2012 (OECD, 2013). The ex-socialist countries are also geo-politically significant as they border China, Iran, and Turkey, and some are European Union members. Studying transition economies as a group is appropriate

\footnotetext{
${ }^{2}$ This paper uses the list of advanced economies from the International Monetary Fund (IMF) Appendix Table B (2014). This comprises the following 30 countries: Austria, Australia, Belgium, Canada, Cyprus, Denmark, Finland, France, Germany, Hong Kong, Greece, Iceland, Ireland, Israel, Italy, Japan, Korea, Luxembourg, Malta, Netherlands, New Zealand, Norway, Portugal, Singapore, Spain, Sweden, Switzerland, Taiwan, United Kingdom, United States. Gallup does not poll San Marino. While the IMF considers the Czech Republic, Estonia, Latvia, Slovakia, and Slovenia advanced economies, we include them in the source countries list.

${ }^{3}$ Over 10 million migrants from these post-socialist nations (about 14 percent of all migrants) live in the advanced OECD countries (OECD, 2008).
} 
as many of them have similar economic conditions and face comparable migration regimes and restrictions. ${ }^{4}$ While migrants from transition economies are a rather homogenous group, we exploit the variation in migrants' experiences in the destination countries to analyze the well-being consequences of migration.

Studying the well-being consequences of migration is policy-pertinent for several reasons. From the destination governments' point of view, immigrant quality of life is instrumentally important for social outcomes such as public health and productivity (De Neve, Diener, Tay, and Xuereb, 2013). For example, positive affect and happiness have beneficial impacts on labor market productivity (Oswald, Proto, \& Sgroi, 2009), income (De Neve \& Oswald, 2012; Graham, Eggers, \& Sukhtankar, 2004), and health (Graham, et al., 2004). Happier immigrants are therefore less likely to be dependent on the host nations' welfare and healthcare systems and may integrate more easily (Ivlevs, 2014). Immigrant life dissatisfaction may, however, be symptomatic of lack of assimilation or social exclusion (Safi, 2010; Sen, 2000). From the sending countries' perspective, emigrant well-being is important not only for issues related to brain drain but also as migrants send remittances and contribute through investments, the spread of ideas, and technology.

This study makes several contributions to the extant literature. First, instead of focusing on a single quality of life dimension, it estimates migration's effects on three well-being metrics,

\footnotetext{
${ }^{4}$ Transition economies share a common socialist past, recently underwent or are still going through transitions to democracy and market economy, are geographically close, and culturally similar. While severely restricted during socialism, emigration from Central and Eastern Europe (CEE) and the Former Soviet Union (FSU) rose after 1989. Opening the borders, combined with political and economic instability, and ethnic conflict in some countries, induced many transition citizens to vote with their feet. While about 130,000 emigrants left these socialist states to live in advanced economies between 1980 and 1987, more than 1 million emigrated each year between 1990 and 1994 (UN, 2002). The transition countries are: Albania, Armenia, Azerbaijan, Belarus, Bosnia and Herzegovina, Bulgaria, Croatia, Czech Republic, Estonia, Georgia, Hungary, Kazakhstan, Kosovo, Kyrgyz Republic, Latvia, Lithuania, Macedonia FYR, Moldova, Mongolia, Montenegro, Poland, Romania, Russian Federation, Serbia, Slovak Republic, Slovenia, Tajikistan, Turkmenistan, Ukraine, Uzbekistan. Post transition-countries are the ten member states which joined the EU between 2004-2007 (EU-10): Bulgaria, Czech Republic, Estonia, Hungary, Latvia, Lithuania, Poland, Romania, Slovakia, and Slovenia. Croatia joined the EU in July 2013.
} 
namely income (PPP-adjusted), life satisfaction, and freedom satisfaction. As such, this paper recognizes that measuring the causes and consequences of migration relying on objective measures (such as income, wages, and employment) provides an incomplete perspective of the true socio-economic impacts of this phenomenon. Second, it studies migration from transition economies to advanced countries. Third, it employs a methodology combining propensity score matching (PSM) and difference-in-differences (DID) to discern, to the extent possible, wellbeing changes caused by migration. Our results imply that by voting with their feet, migrants from transition economies achieve higher perceived and actual well-being and quality of life.

Though not specific to transition economies, research suggests that migrants positively affect destination countries' fiscal outcomes (OECD, 2013) and natives' subjective well-being (Akay, Constant, \& Giulietti, 2014; Betz \& Simpson, 2013). In addition, Dustmann et al. (2010) show that Central and Eastern European migrants from the 2004 EU enlargement are almost 60 percent less likely than natives to receive various forms of public assistance in the UK. In conjunction with our findings, these results imply that migration from transition economies might present substantial development opportunities for both receiving and sending countries.

\section{Literature and Theory}

\subsection{Well-being and Migration}

We build on scholarship related to well-being measurement and on the literature on the well-being effects of migration. First, SWB studies have burgeoned amidst the growing consensus that income-based metrics are insufficient to understand all aspects of the human condition, especially given that objective well-being can coexist with un-happiness and frustration (Stiglitz, Sen, \& Fitoussi, 2009). While economists prefer studying revealed choice and income as opposed to self-reported subjective states, Easterlin's seminal study (1974) used 
self-reported happiness data to examine their relationship with economic growth and income. Building on early contributions to happiness economics (Morawetz et al., 1977; Oswald, 1997; Tinbergen, 1991; Winkelmann \& Winkelmann, 1998), $\operatorname{Ng}(1996,1997)$ proposed that happiness is measurable while Kahneman et al.'s (1997) paper furnished an axiomatic defense of experienced utility and suggested applications to economics (Di Tella, MacCulloch, \& Oswald, 2001). Several decades of research have demonstrated that the key SWB determinants are consistent across different societies and levels of development (Dolan, Peasgood, \& White, 2008; Graham, 2009; Helliwell, Barrington-Leigh, Harris, \& Huang, 2010). There is, moreover, a consensus that SWB metrics are valid and reliable, psychometrically sound, and comparable across respondents (Diener, Inglehart, \& Tay, 2013; Diener, Suh, Lucas, \& Smith, 1999; OECD, 2011, Helliwell and Barrington-Leih, 2010). Specifically regarding comparability, DiTella and MacCulloch (2006) conclude that problems related to interpersonal comparisons of SWB scores are mitigated or eliminated when considered in groups and Durand and Smith (2013) explain that as they are "self-anchoring," life evaluation scales are less sensitive to how people use measurement scales. Finally, data from 160 countries from around the world show that people's SWB scores are determined by similar circumstances and in the same way (Graham, 2009; Helliwell and Barrington-Leigh, 2010).

Second, the income increases due to migration could be as high as 260-270 percent (Clemens, et al., 2008; McKenzie, et al., 2010). Despite this, studies using cross-sectional data show that internal and international migrants experience unhappiness (Bartram, 2011; De Jong, Chamratrithirong, \& Tran, 2002; Knight \& Gunatilaka, 2010; Safi, 2010; Stillman, et al., forthcoming). ${ }^{5}$ Comparing the outcomes of migrants and stayers is misleading, as well-being

\footnotetext{
${ }^{5}$ In one exception, Erlinghagen (2012) finds that German movers are happier and more satisfied with their lives than stayers.
} 
gains (or losses) may actually reflect unobserved differences in ability, risk tolerance, and motivation (McKenzie, et al., 2010). Obtaining causal estimates is difficult in the absence of experiments and panel data tracing migrants before and after leaving. In addition, because SWB studies predominantly use cross-sectional data to compare migrants and natives in destination countries (Baltatescu, 2007; Bartram, 2010; Safi, 2010) or movers and stayers in the sending countries (Bartram, 2013; Erlinghagen, 2012), they cannot adequately demonstrate migration's causal impacts. ${ }^{6}$

Immigrants are unhappier than natives in destination countries, but the result varies by country of origin and the comparison gorup (Simpson, 2014). First, in Israel, immigrants from Western Europe are happier than those from the former Soviet countries (Amit, 2010; Amit \& Litwin, 2010). First generation immigrants are happier than their second-generation counterparts (Safi, 2010; Senik, 2011). Second, migrants are less happy than natives in Europe (Baltatescu, 2007; Safi, 2010; Senik, 2011) and the United States (Bartram, 2011). Third, research on internal migrants shows that East-to-West German migration is associated with happiness (Melzer, 2011) while research on Thailand (De Jong, Chamratrithirong, \& Tran, 2002) and Finland (Ek, Koiranen, Raatikka, Järvelin, \& Taanila, 2008) show the opposite result. Using panel data on British internal migrants, Nowok et al. (2011) demonstrate that before migration, migrants experience unhappiness, then they experience happiness during the process of migration, but their happiness declines post-migration. Some of the divergent findings in the literature could be due to timing - i.e., measuring migration's effects on well-being at different points in time. ${ }^{7}$

Birth country is also pivotal for explaining differences between the earnings of migrants with the same skills but coming from different political and economic conditions (Borjas, 1987).

\footnotetext{
${ }^{6}$ For an exception, see Stillman et al. (2015).

${ }^{7}$ Bartram shows that migrants from Northern (Belgium, Switzerland, France, Germany, Britain, and the Netherlands) to Southern Europe (Spain, Portugal, Greece and Cyprus) are less happy (Bartram, 2014).
} 
Bartram (2013) also finds that after controlling for selection into migration, Central and Eastern European (CEE) migrants are not happier than stayers, though there is a positive effect of migration on happiness among migrants from Russia, Turkey, and Romania, and a negative effect for Polish migrants.

Furthermore, the consequences of migration depend on the well-being outcome. Based on experimental data from an immigration lottery of Tongans leaving for New Zealand, Stillman et al. (2015) find that movers' hedonic well-being declined despite income improvements in income, mental well-being, and income adequacy perceptions. Building on the extant literature, this study assesses migration's effects on three well-being outcomes: real annual household income, subjective well-being (i.e., global life evaluation), and satisfaction with freedom.

\subsection{Migration Theories}

International migration theories generally assume that income maximization motivates the migration decision. For example, micro-level theories view moving as the resultant of a costbenefit calculation by rational actors seeking to maximize the net monetary gain from migration (Massey et al., 1993). An extension of the classic Roy model predicts, for instance, that if earnings in the source and destination countries depend on a single factor which is transferable across borders and there are no migration costs, a worker will move to a destination country which maximizes his or her earnings (Borjas, 2014). ${ }^{8}$ In addition, macro-level models predict that international migration is due to the wage differentials between countries and that labor markets are the most important drivers of migration (Massey, et al., 1993).

A large empirical literature has examined migration policies and push- and pull- factors determining the global movement of people (Beine and Parsons, 2012; de Haas, 2011; Hatton

\footnotetext{
${ }^{8}$ The relative skill transferability across borders and country-specific knowledge and experiences are also relevant when selecting a host country (Danzer \& Dietz, 2014).
} 
and Williamson, 2002; Mayda, 2010; Zimmermann, 1996). The drivers of economic migration include absolute and relative poverty (Czaika \& de Haas, 2012; Stark \& Taylor, 1989), (dis)satisfaction with public goods (Dustmann and Okatenko, 2014), institutions (Bertocchi \& Strozzi, 2008), the income gap between origin and destination countries and the destination's immigration laws (Ortega \& Peri, 2009), among others. In addition, migrant networks furnish information, help, and ethnic goods to movers (Bauer, Epstein, \& Gang, 2000). These results suggest that while important, economic concerns are not the only drivers of the international movement of people. Non-economic factors and quality of life aspirations are also relevant. For instance, Graham and Markowitz (2011) were the first to show that respondents from Latin America with higher than average incomes but lower than average happiness scores are more likely to express emigration intentions.

Specifically for transition economies, Polish movers migrate to improve their household's relative income position in the community (Stark, Micevska, \& Mycielski, 2009). ${ }^{9}$ The children of former Latvian migrants are more likely to migrate, meanwhile (Ivlevs \& King, 2012b). More educated respondents from Kosovo and Albania are also more likely to emigrate (Ivlevs \& King, 2012a; Papapanagos \& Sanfey, 2001) and so are male Albanians, and free market supporters (Papapanagos \& Sanfey, 2001). Blanchflower and Shadforth (2009) discover that the migration propensity from the ex-socialist countries which joined the European Union in 2004 is, unsurprisingly, inversely correlated with GDP per capita in the origin country, as well as with life satisfaction. They also find that migration propensity is positively associated with unemployment rates.

\footnotetext{
${ }^{9}$ Inequality, population density, and the net interregional migration rate are positively related to Polish emigration; unemployment has a negative association but absolute income and poverty have no influence (Stark et al., 2009).
} 


\subsection{Analytical Model}

We posit that the migration decision is motivated by a desire to enhance one's quality of life, defined and measured using a range of perceived and actual well-being indicators. This section presents a simple model of the individual migration decision (Sjaastad, 1962). Let $U_{i t}$ be the individual utility at time $t, U_{i t^{\prime}}$ be the expected utility after migration at time $t^{\prime}$, and $C_{i t, t^{\prime}}$ be the monetary and psychological costs of migration. Moving costs include: direct expenses such as transportation costs, language courses, and visa fees; opportunity costs of foregone earnings and opportunities at home, and psychological costs related to separation from family and friends. In each time period, $U_{i}$ is a function of income and consumption (I), subjective well-being $(\mathrm{H})$, and freedoms and opportunities (F). Specifically:

$$
\begin{aligned}
& \mathrm{U}_{\mathrm{it}}=\mathrm{U}_{\mathrm{t}}\left(\mathrm{u}_{1}\left(\mathrm{I}_{\mathrm{it}}\right), \mathrm{u}_{2}\left(\mathrm{H}_{\mathrm{it}}\right), \mathrm{u}_{3}\left(\mathrm{~F}_{\mathrm{it}}\right)\right) \text { and } \\
& \mathrm{U}_{\mathrm{it}^{\prime}}=\mathrm{U}_{\mathrm{t}^{\prime}}\left(\mathrm{u}_{1}\left(\mathrm{I}_{\mathrm{it}^{\prime}}\right), \mathrm{u}_{2}\left(\mathrm{H}_{\mathrm{it}^{\prime}}\right), \mathrm{u}_{3}\left(\mathrm{~F}_{\mathrm{it}^{\prime}}\right)\right)
\end{aligned}
$$

where $u_{1}$ (.), $u_{2}$ (.), and $u_{3}$ (.) are the respective sub-utility functions for consumption, subjective well-being, and freedom, respectively, and are increasing at a decreasing rate in their argument. Each sub-utility in each time period is conditional on individual characteristics.

An individual $i$ living in a transition economy considers whether to relocate to an advanced economy if the expected utility from migration exceeds its pecuniary and psychological costs $U_{i t^{\prime}}-U_{i t}>C_{i t, t^{\prime}}$. The probability of migration $\operatorname{Pr}\left(\mathrm{M}=1 \mid \mathrm{X}_{\mathrm{i}}\right)=\operatorname{Pr}\left(U_{i t^{\prime}}-U_{i t}-\right.$ $\left.C_{i t, t^{\prime}}>0 \mid \mathrm{X}_{\mathrm{i}}\right)$. 


\section{Estimation Strategy \\ 3.1.Empirical Challenges and Objectives}

Self-selection, i.e., the fact that migrants differ from stayers in terms of risk tolerance, skills, motivation, and wealth, is the main challenge for assessing the causal impact of migration on well-being (McKenzie, 2012). For example, migrants have higher aspirations (Czaika \& Vothknecht, 2014) and may be less risk-averse than non-migrants and risk preferences may also be correlated with well-being outcomes. Reverse causality is another methodological concern. For instance, while migration may affect happiness, those dissatisfied with their lives are more likely to migrate (Cai, Esipova, Oppenheimer, \& Feng, 2014; Chindarkar, 2014; Graham \& Markowitz, 2011; Otrachshenko \& Popova, 2014). ${ }^{10}$ Moreover, if migration is costly, relatively well-off individuals will be more likely to migrate and a cross-sectional comparison would simply pick the effect of pre-migration status on post-moving income.

While studies have dealt with selection and reverse causality in several ways, including assuming selection on observables, using instrumental variables, and matching, only experimental data can establish causality. ${ }^{11}$ In the absence of an experiment and a panel tracing migrants before and after moving, we use available pooled cross-sectional data and statistical matching to create a two-period synthetic panel of observably similar migrants and stayers. We then employ DID to assess the effects of migration on well-being. To our knowledge, this is the first paper employing this methodology in the context of international migration. ${ }^{12}$

\footnotetext{
${ }^{10}$ In one exception, using instrumental variables, Ivlevs (2014) discovers that potential migrants from transition economies are positively selected on life satisfaction.

${ }^{11}$ Under certain conditions, non-experimental methods such as difference-in-differences (DID) produce results that are reasonably close to experimental findings (McKenzie et al., 2010).

${ }^{12}$ Sandi and Winters (2014) apply a similar methodology in the context of internal migration.
} 
Let $\mathrm{M}_{\mathrm{it}} \in\{0,1\}$ be an indicator for whether transition country migrant $i$ moved to an

advanced country in time period $t$. Let $\mathrm{Y}_{\mathrm{it}}$ be the well-being outcome before migration and $\mathrm{Y}_{\mathrm{it}}$ be the well-being outcome post-migration. The causal effect of migration is:

$$
\mathrm{Y}_{\mathrm{it}^{\prime}}-\mathrm{Y}_{\mathrm{it}}
$$

Because the counterfactual outcome $Y_{\text {it }}$ is unobserved, the estimation focuses on the average treatment effects (ATT) (Caliendo \& Kopeinig, 2008):

$\mathrm{E}\left\{\mathrm{Y}_{\mathrm{t}^{\prime}}-\mathrm{Y}_{\mathrm{t}} \mid \mathrm{M}=1\right\}=\mathrm{E}\left\{\mathrm{Y}_{\mathrm{t}^{\prime}} \mid \mathrm{M}=1\right\}-\mathrm{E}\left\{\mathrm{Y}_{\mathrm{t}} \mid \mathrm{M}=1\right\}$

As they are unobserved, the counterfactual mean outcomes $\mathrm{E}\left\{\mathrm{Y}_{\mathrm{t}} \mid \mathrm{M}=1\right\}$ (i.e., the wellbeing outcome of migrants had they not migrated) must be constructed using statistical methods. Using the well-being outcomes of those who did not migrate $\mathrm{E}\left\{\mathrm{Y}_{\mathrm{t}} \mid \mathrm{M}=0\right\}$ as a counterfactual will not deal with selection problems as factors that influence selection into migration likely also affect the well-being outcomes (Caliendo \& Kopeinig, 2008). In summary, our empirical strategy comprises two major steps: (i) identifying migrants and stayers before and after migration (i.e., four analysis groups in total) and (ii) computing the DID for their well-being outcomes (i.e., household income, evaluative well-being, and satisfaction with freedom).

\subsection{Analysis Groups}

Based on a discussion in Blundell and Costa Dias (2000), for each migrant after migration, we use PSM to find an observably similar migrant counterpart before migration, and then apply PSM again to find observably similar stayers for before and after comparisons, with the end-goal being the creation of a synthetic panel with the following analysis groups (see figure 1 and table 1). 
Figure 1. Analysis Groups

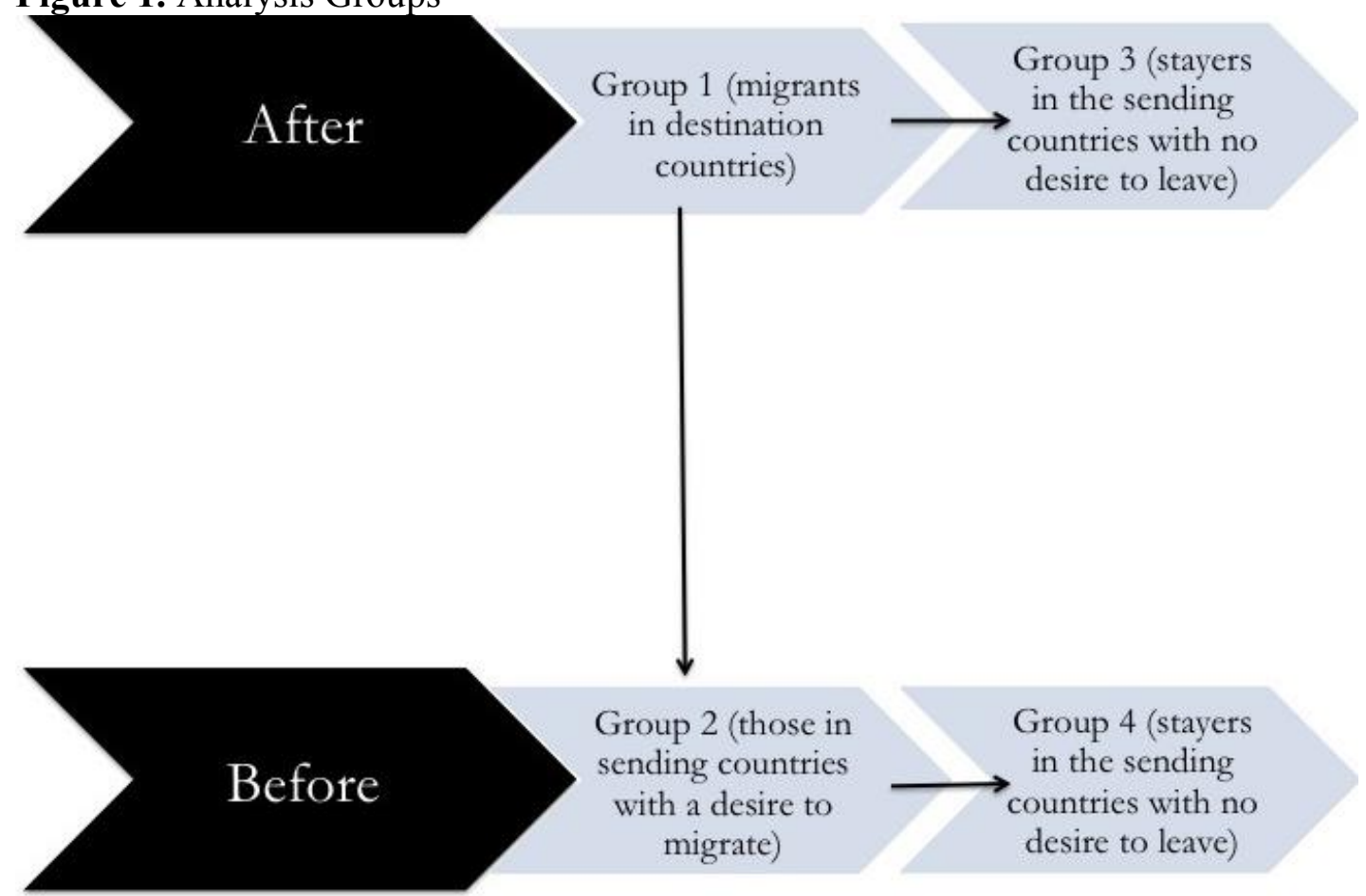

Source: Authors.

Table 1. Analysis Groups

\begin{tabular}{|c|c|c|}
\hline Time period/Location & Before & After \\
\hline In home country & $\begin{array}{l}\text { Group } 2 \\
\text { (identified in the sample of } \\
\text { transition economies, among those } \\
\text { expressing a desire to move; in a } \\
\text { separate analysis, among those with } \\
\text { a plan to move; statistical matching } \\
\text { with Group 1) } \\
\text { Group } \mathbf{3} \\
\text { (identified in the sample of } \\
\text { transition economies, among those } \\
\text { expressing no desire or plans to } \\
\text { move; statistical matching with } \\
\text { Group 1) }\end{array}$ & $\begin{array}{l}\text { Group } 4 \\
\text { (identified in the sample of } \\
\text { transition economies, } \\
\text { among those expressing } \\
\underline{\text { no desire or plans to }} \\
\text { move; statistical matching } \\
\text { with Group 2) }\end{array}$ \\
\hline In destination & & $\begin{array}{l}\text { Group } 1 \\
\text { (identified in the sample of } \\
\text { advanced economies } \\
\text { through a survey question } \\
\text { on country of birth) }\end{array}$ \\
\hline
\end{tabular}

Source: Authors. 
Group 1. This group comprises migrants from transition countries after they moved to advanced economies (i.e., the treatment group after migration at time $t^{\prime}$ ). GWP asks respondents whether they were born in the country of interview, and if not, in which country they were born, allowing us to identify immigrants from transition countries.

Group 2. This group comprises migrants before leaving at time $t$. For each migrant in Group 1, we identify a "migrant before migration" using probability matching combined with exact matching. Specifically, we match migrants in Group 1 with respondents who expressed a desire to move permanently to another country using age, age squared, gender, religion, education, country of origin, and destination country. We use exact matching to ensure that the match is from the same country of origin, will move to the same destination country, is of the same gender and religion, and has the same educational attainment. After matching, we deleted matched pairs if the match's age is greater than the migrant's.

Group 3. This group comprises non-migrants observed at time $t^{\prime}$ identified by matching Group 1 with stayers based on age, age squared, gender, religion, education, and country of origin. We imposed exact matching by country of origin, year of interview, gender, religion, and education.

Group 4. This group comprises non-migrants at time t (i.e., before migration) matched with migrants before migration in Group 2 using an identical procedure as the matching of Groups 3 and 1.

\subsection{Creating Synthetic Cohorts with Matching ${ }^{13}$}

Let $X$ be a vector of pre-migration characteristics (i.e., the conditioning variables). The propensity score $P(X)$ is the conditional probability of migrating given the conditioning

\footnotetext{
${ }^{13}$ For detailed overviews of the theoretical, practical, and methodological aspects of PSM, see (Blundell \& Costa Dias, 2000; Caliendo \& Kopeinig, 2008; Dehejia \& Wahba, 2002; Rosenbaum \& Rubin, 1983; Shadish \& Steiner, 2010; Smith \& Todd, 2005; Stuart, 2010; Todd, 2006).
} 
variables. Given the assumptions of unconfoundedness and common support, the propensity score, or the conditional probability of migrating, is: $\mathrm{P}(\mathrm{X})=\operatorname{Pr}(\mathrm{M}=1 \mid \mathrm{X})$.

We explain the matching of migrants and non-migrants as the procedure is analogous for matching potential with actual migrants. ${ }^{14}$ We first estimate the propensity scores using a logit model:

$$
\mathrm{M}_{\mathrm{i}}=\alpha_{1}+\beta^{\mathrm{M}} \mathrm{X}_{\mathrm{i}}+\mathrm{u}_{\mathrm{i}}
$$

where $\mathrm{M}=1$ if the individual from a transition economy migrated to an advanced economy and 0 if he or she stayed in the home country. We excluded stayers in the sending countries who were foreign-born and those who wanted or planned to move. Prior to matching, we also excluded respondents with missing observations for any of the covariates or the outcome variables. $X_{i}$ is a vector of socio-demographic characteristics predicting migration: age, age squared, gender, indicators for religious affiliation, country of origin, indicators for whether the respondent has elementary, secondary, or tertiary education, year of interview, and country of origin. Note that the treatment (i.e., migration) cannot influence the matching variables (Heinrich et al., 2010; Smith \& Todd, 2005), which is why the matching covariates exclude marital and

\footnotetext{
${ }^{14}$ Groups 1 and 2 (migrants and potential migrants before migration) are considered the "treatment" and groups 3 and 4 (stayers) are considered the "controls." Group 1 are actual immigrants observed in the host country of interview. The other groups are obtained by statistical matching. As a first step, we matched immigrants with potential migrants using observations from the entire sample regardless of the year of interview. At this stage, to ensure age comparability, we deleted matched pairs if the immigrant was younger than the potential migrant. We acknowledge that there could be timing issues since the exact year of migration is unknown. Specifically, a potential bias could be due to the fact that the matching is done with age while ideally, it should be done with age at migration. Unfortunately, we do not have detailed information about when the migrant migrated. We only have information on whether the migrant arrived in the host country 5 years ago or more. Due to the limited number of observations, we do not distinguish between migrants who arrived in the host country in the past five years or later. It is difficult to understand the size of this bias but it is a function of the average years since migration. As a second step, we combined migrants and their matched potential migrants in a merged data file. We created indicator variables for group 1 and group 2. By construction, group 1 is observed in the period after migration and group 2 is observed in the period before migration. Both these periods span the survey period of 2008-2013. In the third step, we used this merged data file of "migrants" to match it with non-migrants. In the next step, we used year as one of the covariates for exact matching (in addition to age, gender, education, and religion) to ensure that the migrant and the stayer are observed in the same year. We checked that this condition was satisfied. The matches for group 1 (i.e., group 3 ) by construction belong to the period after migration and by construction, the matches for group 2 (i.e., group 4) belong to the period before migration.
} 
employment status, and income. While education may not be independent of migration, we included it as it is an important proxy for ability, intelligence, and skills.

After computing the propensity score, we used one-to-one nearest neighbor matching without replacement with a caliper (i.e., maximum allowable distance between the propensity scores) of $0.01 .{ }^{15}$ We excluded migrants without a match within the caliper, which increases the confidence that the matching is balanced but reduces the number of observations. Since the goal is to create matches that are as similar as possible, we use exact matching by country of birth, year, gender, religion, and education.

Next, we checked whether the balancing property was satisfied using $t$-tests for the equality of means in the treated and non-treated groups after matching. The differences are statistically insignificant for all matching covariates, indicating that the balancing property is satisfied. Migrants and non-migrants have identical values for education, gender, and religion. Finally, we only kept exact matches to create a balanced synthetic panel of migrants and nonmigrants before and after migration. Each group includes 167 observations (see tables 2 and 3).

\footnotetext{
${ }^{15}$ We used the -psmatch2- module in Stata developed by Leuven and Sianesi (2003).
} 
Table 2. Analysis Sample, Source and Destination Countries

\begin{tabular}{lcc|lcc}
\hline Birth Country & Freq. & Percent & Residence Country & Freq. & Percent \\
\hline Poland & 28 & 16.770 & Germany & 28 & 16.770 \\
Romania & 27 & 16.170 & Greece & 27 & 16.170 \\
Albania & 21 & 12.570 & Austria & 21 & 12.570 \\
Russia & 14 & 8.380 & Italy & 20 & 11.980 \\
Serbia & 12 & 7.190 & Spain & 17 & 10.180 \\
Lithuania & 10 & 5.990 & Ireland & 12 & 7.190 \\
Croatia & 8 & 4.790 & Sweden & 8 & 4.790 \\
Slovenia & 7 & 4.190 & Australia & 8 & 4.790 \\
Bosnia and Herzegovina & 6 & 3.590 & Switzerland & 8 & 4.790 \\
Bulgaria & 6 & 3.590 & Finland & 5 & 2.990 \\
Georgia & 5 & 2.990 & United States & 2 & 1.200 \\
Moldova & 5 & 2.990 & France & 2 & 1.200 \\
Kosovo & 5 & 2.990 & Denmark & 2 & 1.200 \\
Hungary & 4 & 2.400 & Canada & 2 & 1.200 \\
Ukraine & 2 & 1.200 & United Kingdom & 1 & 0.600 \\
Latvia & 2 & 1.200 & Belgium & 1 & 0.600 \\
Macedonia & 2 & 1.200 & New Zealand & 1 & 0.600 \\
Czech Republic & 1 & 0.600 & Luxembourg & 1 & 0.600 \\
Kazakhstan & 1 & 0.600 & Norway & 1 & 0.600 \\
Montenegro & 1 & 0.600 & & & \\
\hline Total & $\mathbf{1 6 7}$ & $\mathbf{1 0 0 . 0 0 0}$ & Total & $\mathbf{1 6 7}$ & $\mathbf{1 0 0 . 0 0 0}$ \\
\hline
\end{tabular}

Source: Authors' calculations based on the Gallup World Poll, 2008-2013 
Table 3. Summary Statistics, Analysis Sample

\begin{tabular}{|c|c|c|c|c|c|c|c|c|}
\hline \multirow[b]{2}{*}{ Variables } & \multicolumn{2}{|c|}{$\begin{array}{l}\text { Migrants After } \\
\text { Group } 1\end{array}$} & \multicolumn{2}{|c|}{$\begin{array}{c}\text { Migrants Before } \\
\text { Group } 2\end{array}$} & \multicolumn{2}{|c|}{$\begin{array}{l}\text { Stayers After } \\
\text { Group } 3\end{array}$} & \multicolumn{2}{|c|}{$\begin{array}{l}\text { Stayers Before } \\
\text { Group } 4\end{array}$} \\
\hline & Mean & Std. Dev. & Mean & Std. Dev. & Mean & Std. Dev. & Mean & Std. Dev. \\
\hline \multicolumn{9}{|l|}{ Outcome Variables } \\
\hline Household Income (in 1,000 s ID) & 34.203 & 30.447 & 14.084 & 15.898 & 14.106 & 11.363 & 14.326 & 17.429 \\
\hline HH Income Per HH Member (in 1,000s ID) & 15.816 & 14.494 & 5.334 & 5.249 & 5.935 & 4.899 & 6.150 & 6.502 \\
\hline Best Possible Life (BPL) (1-10) & 6.305 & 2.085 & 5.096 & 2.226 & 5.485 & 1.894 & 5.389 & 2.292 \\
\hline Satisfaction with Freedom & 0.832 & 0.375 & 0.575 & 0.496 & 0.713 & 0.454 & 0.695 & 0.462 \\
\hline \multicolumn{9}{|l|}{ Matching Variables } \\
\hline Age & 40.305 & 12.815 & 38.353 & 13.355 & 40.557 & 13.458 & 39.581 & 13.034 \\
\hline Female $(1=$ Yes $)$ & 0.563 & 0.498 & 0.563 & 0.498 & 0.563 & 0.498 & 0.563 & 0.498 \\
\hline Catholic (1=Yes) & 0.359 & 0.481 & 0.359 & 0.481 & 0.359 & 0.481 & 0.359 & 0.481 \\
\hline Protestant $(1=$ Yes $)$ & 0.018 & 0.133 & 0.018 & 0.133 & 0.018 & 0.133 & 0.018 & 0.133 \\
\hline Orthodox $(1=$ Yes $)$ & 0.449 & 0.499 & 0.449 & 0.499 & 0.449 & 0.499 & 0.449 & 0.499 \\
\hline Muslim (1=Yes) & 0.144 & 0.352 & 0.144 & 0.352 & 0.144 & 0.352 & 0.144 & 0.352 \\
\hline Muslim: Sunni (1=Yes) & 0.012 & 0.109 & 0.012 & 0.109 & 0.012 & 0.109 & 0.012 & 0.109 \\
\hline No religion/Agnostic $(1=$ Yes $)$ & 0.018 & 0.133 & 0.018 & 0.133 & 0.018 & 0.133 & 0.018 & 0.133 \\
\hline Elementary Education ( $1=$ Yes $)$ & 0.072 & 0.259 & 0.072 & 0.259 & 0.072 & 0.259 & 0.072 & 0.259 \\
\hline Completed Secondary Education $(1=$ Yes $)$ & 0.749 & 0.435 & 0.749 & 0.435 & 0.749 & 0.435 & 0.749 & 0.435 \\
\hline Some College Education/ & & & & & & & & \\
\hline College Graduate $(1=\mathrm{Yes})$ & 0.180 & 0.385 & 0.180 & 0.385 & 0.180 & 0.385 & 0.180 & 0.385 \\
\hline
\end{tabular}

Source: Authors' calculations based on the Gallup World Poll, 2008-2013.

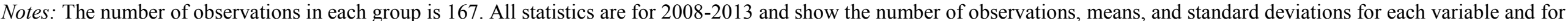

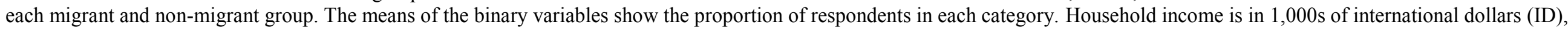

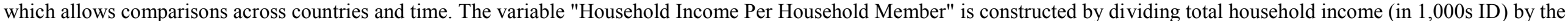
number of household members. 
Of course, labeling respondents expressing a desire to move permanently to another country "migrants before migration" requires that they will in fact subsequently move to the destination they indicated. Research suggests that this assumption is plausible as intentions are good predictors of actual migration (Creighton, 2013; van Dalen \& Henkens, 2008, 2013). We also offer a robustness check by matching actual migrants with respondents with concrete migration plans.

\subsection{Parametric Difference-in-Differences Estimator}

After creating the synthetic panel, we calculated the parametric difference-in-differences (DID). The parameter of interest is:

$$
\left(\mathrm{Y}_{\mathrm{t}^{\prime}}-\mathrm{Y}_{\mathrm{t}}^{\mathrm{M}}\right)-\left(\mathrm{Y}_{\mathrm{t}^{\prime}}^{\mathrm{S}}-\mathrm{Y}_{\mathrm{t}}^{\mathrm{S}}\right)
$$

where the superscripts ${ }^{\mathrm{M}}$ and ${ }^{\mathrm{S}}$ designate migrants and stayers, respectively. We obtain the DID estimate using the pooled cross-sectional synthetic cohort data from the following regression:

$Y_{i t}=\beta_{0}+\beta_{1} M_{i}+\beta_{2} T_{t}+\beta_{3} M_{i} * T_{t}+X_{i t} \pi+\varepsilon_{i t}$

where $M$ is a binary indicator for migrant or stayer, $T$ is an indicator for period before or after migration, and $X$ is a vector of individual characteristics (age, age squared, gender, education, religion, and country of origin). Note that $\beta_{2}$ is the difference in outcomes between movers and stayers pre-migration, while $\beta_{2}+\beta_{3}$ is the difference in their outcomes postmigration. The DID (or the causal effect of migration on the outcome) is measured by $\beta_{3}$. All equations are estimated using OLS with robust standard errors and the Gallup-provided survey weight. OLS is appropriate as the interpretation of the interaction term in non-linear models with a monotonic transformation functions is problematic (Ai \& Norton, 2003). In addition, 
estimating ordinal SWB data using OLS or ordered logits and probits produces similar results (Ferrer-i-Carbonell \& Frijters, 2004; Frijters \& Beatton, 2012).

The DID estimator's main assumption is that changes which occurred for reasons other than migration impacted migrant and non-migrant groups in the same way (Abadie, 2005). One such factor was the global economic crisis and to the extent that it affected all analysis countries similarly, the DID estimation allows one to separate its influence from the effect of migration. ${ }^{16}$ While the pre-treatment characteristics for the mover and stayer groups are observably similar, the effect of the global crisis likely varied across the countries in the analysis sample. Note also that the DiD estimator assumes that the costs of migration are constant across Groups 1 and 2, so that they can be netted out through the differencing. We are constrained by data limitations and the DID estimator is the best available alternative.

\section{Data and Summary Statistics}

\subsection{Data}

The data are from the Gallup World Poll (GWP), which is an annual survey conducted by the Gallup Organization in about 160 countries, representing about 98 percent of the world's adult population. GWP polled all 30 transition countries at least three times during the 20052013 period. GWP is probability-based and nationally representative (of populations aged 15 and over), polling about 1,000 individuals per country and over-sampling some countries such as Russia. While not specifically designed to study migration, GWP's comprehensiveness enables the analysis of immigrants and their experiences (Esipova, Pugliese, Ray, \& Kanitkar, 2013). In addition, Gallup researchers weight the data, so that they are comparable between migrants and

\footnotetext{
${ }^{16}$ The parallel trends assumption is unrealistic when pre-treatment characteristics associated with the outcome are un-balanced between the treatment and control groups (Abadie, 2005), which is not the case here.
} 
stayers. ${ }^{17}$ The data are collected using telephone or in-person interviews using the same survey methodology across countries, ensuring comparability across countries and over time. In most transition countries, the interviews are face-to-face and in most advanced countries, the data are collected via landline or cell phone interviews. We emphasize that since Gallup polls different individuals each year, we have pooled cross-sections rather than a panel, which is a limitation that we acknowledge.

\subsection{Outcome Variables}

First, our objective well-being variable is household income, which is calculated in international dollars, allowing comparisons across countries and over time. Specifically, Gallup constructs the household income variable by dividing income in local currency by 2011 PPP ratios. As such, the income metrics take into account cost of living differentials and are therefore comparable across individuals, communities, and over time. Second, the SWB indicator is the Cantril ladder question on the best possible life (BPL), which asks respondents to compare their life to the best possible life they can imagine, based on an eleven-point scale (Cantril, 1965). Third, freedom perceptions is a binary indicator for whether or not the respondent is satisfied with his or her freedom to choose what to do with his or her life.

\subsection{Summary Statistics}

The analysis sample spans 2008-2013 representing migrants from 20 of the 30 transition economies, including both EU and non-EU members. The top three sending countries are Poland, Romania, and Albania, while the most common destinations are Germany, Greece, and Austria (see table 2). Migrants and stayers are on average in their very late 30 s or early 40 s, about 56 percent are female and about 45 percent are Christian Orthodox (see table 3 ). Across

\footnotetext{
${ }^{17}$ First, the data are weighed using base sampling weights to correct for oversampling and household size. Then, post-stratification weights are constructed - population statistics are used to weight the data by gender, age, and in some instances, education and socio-economic status. In the DID estimations, we use the Gallup-provided weight.
} 
the board, 75 percent of migrants and stayers have secondary education, while 18 percent are college-educated.

Table 3 also demonstrates that migrants earn considerably more than comparable potential migrants (Group 2) and non-migrants (Groups 3 and 4). Specifically, while the unconditional mean incomes (PPP-adjusted) are about 34,000 ID after migration, they are only about 14,000 ID for the other groups. Migrants also report higher subjective well-being (BPL) and satisfaction with freedom than any other group. The potential migrant group (Group 2) has the lowest BPL score of 5.1 and the lowest percentage of respondents satisfied with freedom (58 percent). We next examine whether these unconditional differences in well-being hold after we implement the DID estimation.

\section{Results}

\subsection{Main Results}

Table 4 shows the DID estimation results. Models (1)-(4) are estimated without additional covariates. The baseline findings are robust to including the individual-level controls and country of origin indicators in (5)-(8). Specifically, migration leads to an unequivocal increase in material well-being: the household income premium (with and without controls for observable characteristics including education) is about 21,000 ID (10,500 ID per household member). 
Table 4. Main Results

\begin{tabular}{|c|c|c|c|c|c|c|c|c|}
\hline & \multicolumn{4}{|c|}{ Full Sample No Covariates } & \multicolumn{4}{|c|}{ Full Sample With Covariates } \\
\hline & $\begin{array}{c}\text { (1) } \\
\text { Household } \\
\text { Income }\end{array}$ & $\begin{array}{c}(2) \\
\text { HH Income } \\
\text { Per HH } \\
\text { Member }\end{array}$ & $\begin{array}{r}\text { (3) } \\
\text { BPL } \\
\end{array}$ & Freedom & $\begin{array}{c}\text { (5) } \\
\text { Household } \\
\text { Income }\end{array}$ & $\begin{array}{c}6) \\
\text { HH Income } \\
\text { Per HH } \\
\text { Member } \\
\end{array}$ & BPL & Freedom \\
\hline Migrant (1=Yes) & $\begin{array}{c}0.815 \\
(1.966)\end{array}$ & $\begin{array}{l}-0.278 \\
(0.647)\end{array}$ & $\begin{array}{l}-0.073 \\
(0.279)\end{array}$ & $\begin{array}{c}-0.121 * * \\
(0.061)\end{array}$ & $\begin{array}{c}0.098 \\
(1.933)\end{array}$ & $\begin{array}{l}-0.586 \\
(0.639)\end{array}$ & $\begin{array}{l}-0.199 \\
(0.259)\end{array}$ & $\begin{array}{c}-0.134 * * \\
(0.059)\end{array}$ \\
\hline $\begin{array}{l}\text { After Migration } \\
(1=\text { Yes })\end{array}$ & $\begin{array}{c}-0.034 \\
(1.743)\end{array}$ & $\begin{array}{l}-0.056 \\
(0.628)\end{array}$ & $\begin{array}{c}0.134 \\
(0.290)\end{array}$ & $\begin{array}{c}0.016 \\
(0.060)\end{array}$ & $\begin{array}{l}-0.420 \\
(1.798)\end{array}$ & $\begin{array}{l}-0.402 \\
(0.643)\end{array}$ & $\begin{array}{c}0.093 \\
(0.264)\end{array}$ & $\begin{array}{c}0.012 \\
(0.057)\end{array}$ \\
\hline Migrant*After & $\begin{array}{c}21.226 * * * \\
(3.564)\end{array}$ & $\begin{array}{c}10.470 * * * \\
(1.504)\end{array}$ & $\begin{array}{c}1.043 * * * \\
(0.400)\end{array}$ & $\begin{array}{c}0.261 * * * \\
(0.082)\end{array}$ & $\begin{array}{c}20.900 * * * \\
(3.371)\end{array}$ & $\begin{array}{c}10.515 * * * \\
(1.388)\end{array}$ & $\begin{array}{c}1.171 * * * \\
(0.372)\end{array}$ & $\begin{array}{c}0.276 * * * \\
(0.078)\end{array}$ \\
\hline $\begin{array}{l}\text { Birth Country } \\
\text { Dummies }\end{array}$ & No & No & No & No & Yes & Yes & Yes & Yes \\
\hline Individual Controls & No & No & No & No & Yes & Yes & Yes & Yes \\
\hline $\mathrm{N}$ & 668 & 668 & 668 & 668 & 668 & 668 & 668 & 668 \\
\hline Adjusted $\mathrm{R}^{2}$ & 0.181 & 0.214 & 0.043 & 0.043 & 0.292 & 0.341 & 0.135 & 0.096 \\
\hline
\end{tabular}

Source: Authors' calculations based on the Gallup World Poll, 2008-2013

Notes: Difference-in-Differences estimation using robust standard errors and the Gallup-provided survey weight. Household income is in 1,000s of international dollars (ID), which allows comparisons across countries and time. The variable "Household Income Per Household Member" is constructed by dividing total household income (in 1,000 ID) by the number of household members. Best Possible Life (BPL) measures the respondent's assessment of her current life relative to her best possible life on a scale of 0 to 10 , where 0 is the worst possible life, and 10 is the best possible life. "Freedom" is binary variable coded as 1 if the respondent is satisfied with his or her freedom to choose in life and as 0 otherwise. The individual control variables include: age, age squared, gender, religion dummies, and education.

$* * * \mathrm{p}<0.01, * * \mathrm{p}<0.05, * \mathrm{p}<0.1$ 
Migrants from transition economies not only earn more but also realize SWB gains. The evaluative well-being (BPL) benefit from migration is between 1.0 and 1.2 on an eleven-point scale (when accounting for individual characteristics and country of birth); as such, this "happiness premium" from migration is substantively significant. In addition to boosting incomes and well-being perceptions, migration affects movers' satisfaction with freedom to choose. Movers are about 26-27 percent more satisfied with their freedom due to migration.

Table 5 shows the main results excluding (only using) the top five sending and destination countries. The top part of Table 5 indicates that when we exclude migrants from the most common origin countries (Poland, Romania, Albania, Russia, and Serbia), the household income premium from migration drops slightly to 19,000 ID (9,500 ID per household member), the happiness premium increases to 1.9 , and the satisfaction with freedom benefit is comparable to that in the main specification. Similarly, when we exclude the top five destination countries (Germany, Greece, Austria, Italy, and Spain), the income premium is over 27,000 ID (about 15,000 ID per household member) and the happiness premium is positive but marginally significant. There is a large and significant positive change in the satisfaction with freedom outcome, moreover.

When we focus only on the results based on the top five destination countries, the income premium is smaller in magnitude than that in the main results. The happiness increase is slightly larger in magnitude than the results in Table 4, and the perceptions of freedom DID is smaller and only marginally significant. When we consider only the top five sending countries, the income premium rises to about 22,000 ID, although the BPL DID is less than one (and only marginally significant), despite the improvements in freedom satisfaction. Table 5 indicates that 
the main results shown in Table 4 are generally robust and that migration leads to income and SWB premiums. 
Table 5. DID Results Excluding Top Sending and Destination Countries

\begin{tabular}{|c|c|c|c|c|c|c|c|c|}
\hline & \multicolumn{4}{|c|}{ Excluding Top 5 Sending Countries } & \multicolumn{4}{|c|}{ Only Top 5 Sending Countries } \\
\hline & $\begin{array}{c}(1) \\
\text { Household } \\
\text { Income }\end{array}$ & $\begin{array}{c}(2) \\
\text { HH Income } \\
\text { Per HH Member }\end{array}$ & $\begin{array}{r}(3) \\
\text { BPL }\end{array}$ & Freedom & $\begin{array}{l}\text { (5) } \\
\text { Household } \\
\text { Income }\end{array}$ & $\begin{array}{c}(6) \\
\text { HH Income } \\
\text { Per HH Member }\end{array}$ & $\begin{array}{r}(7) \\
\text { BPL }\end{array}$ & $\begin{array}{c}\text { (8) } \\
\text { Freedom }\end{array}$ \\
\hline Migrant (1=Yes) & $\begin{array}{c}2.257 \\
(2.094)\end{array}$ & $\begin{array}{c}-0.032 \\
(0.800)\end{array}$ & $\begin{array}{l}-0.448 \\
(0.363)\end{array}$ & $\begin{array}{l}-0.100 \\
(0.086)\end{array}$ & $\begin{array}{l}-1.509 \\
(2.975)\end{array}$ & $\begin{array}{l}-1.058 \\
(0.946)\end{array}$ & $\begin{array}{l}-0.036 \\
(0.337)\end{array}$ & $\begin{array}{c}-0.168 * * \\
(0.077)\end{array}$ \\
\hline After Migration (1=Yes) & $\begin{array}{c}1.341 \\
(1.961)\end{array}$ & $\begin{array}{c}0.210 \\
(0.910)\end{array}$ & $\begin{array}{c}0.156 \\
(0.388)\end{array}$ & $\begin{array}{c}0.085 \\
(0.082)\end{array}$ & $\begin{array}{c}-1.858 \\
(2.731)\end{array}$ & $\begin{array}{l}-0.891 \\
(0.925)\end{array}$ & $\begin{array}{c}0.016 \\
(0.353)\end{array}$ & $\begin{array}{c}-0.035 \\
(0.075)\end{array}$ \\
\hline Migrant*After & $\begin{array}{c}19.203 * * * \\
(3.809)\end{array}$ & $\begin{array}{c}9.517 * * * \\
(1.723)\end{array}$ & $\begin{array}{c}1.895 * * * \\
(0.521)\end{array}$ & $\begin{array}{c}0.261 * * \\
(0.111)\end{array}$ & $\begin{array}{c}22.085 * * * \\
(4.960)\end{array}$ & $\begin{array}{c}11.237 * * * \\
(1.978)\end{array}$ & $\begin{array}{c}0.644 \\
(0.491)\end{array}$ & $\begin{array}{c}0.282 * * * \\
(0.105)\end{array}$ \\
\hline Birth Country Dummies & Yes & Yes & Yes & Yes & Yes & Yes & Yes & Yes \\
\hline Individual Controls & Yes & Yes & Yes & Yes & Yes & Yes & Yes & Yes \\
\hline $\mathrm{N}$ & 260 & 260 & 260 & 260 & 408 & 408 & 408 & 408 \\
\hline \multirow[t]{3}{*}{ Adjusted $\mathrm{R}^{2}$} & 0.404 & 0.420 & 0.297 & 0.193 & 0.244 & 0.312 & 0.064 & 0.060 \\
\hline & \multicolumn{4}{|c|}{ Excluding Top 5 Destination Countries } & \multicolumn{4}{|c|}{ Only Top 5 Destination Countries } \\
\hline & $\begin{array}{c}(9) \\
\text { Household } \\
\text { Income } \\
\end{array}$ & $\begin{array}{c}(10) \\
\text { HH Income } \\
\text { Per HH Member }\end{array}$ & $\begin{array}{l}(11) \\
\text { BPL }\end{array}$ & $\begin{array}{c}(12) \\
\text { Freedom } \\
\end{array}$ & $\begin{array}{c}(13) \\
\text { Household } \\
\text { Income } \\
\end{array}$ & $\begin{array}{c}(14) \\
\text { HH Income } \\
\text { Per HH Member }\end{array}$ & $\begin{array}{l}(15) \\
\text { BPL } \\
\end{array}$ & $\begin{array}{c}\text { (16) } \\
\text { Freedom }\end{array}$ \\
\hline Migrant (1=Yes) & $\begin{array}{c}2.961 \\
(2.729)\end{array}$ & $\begin{array}{c}0.297 \\
(1.053)\end{array}$ & $\begin{array}{c}0.227 \\
(0.396)\end{array}$ & $\begin{array}{c}-0.225^{* *} \\
(0.105)\end{array}$ & $\begin{array}{l}-1.161 \\
(2.504)\end{array}$ & $\begin{array}{l}-0.932 \\
(0.787)\end{array}$ & $\begin{array}{l}-0.386 \\
(0.328)\end{array}$ & $\begin{array}{l}-0.095 \\
(0.069)\end{array}$ \\
\hline After Migration (1=Yes) & $\begin{array}{c}2.763 \\
(2.359)\end{array}$ & $\begin{array}{c}0.107 \\
(0.961)\end{array}$ & $\begin{array}{c}0.366 \\
(0.393)\end{array}$ & $\begin{array}{l}-0.005 \\
(0.099)\end{array}$ & $\begin{array}{l}-1.229 \\
(2.347)\end{array}$ & $\begin{array}{l}-0.462 \\
(0.793)\end{array}$ & $\begin{array}{l}-0.029 \\
(0.338)\end{array}$ & $\begin{array}{c}0.029 \\
(0.068)\end{array}$ \\
\hline Migrant*After & $\begin{array}{c}27.295 * * * \\
(5.569)\end{array}$ & $\begin{array}{l}15.158 * * * \\
(2.571)\end{array}$ & $\begin{array}{l}1.009 * \\
(0.555)\end{array}$ & $\begin{array}{c}0.466 * * * \\
(0.132)\end{array}$ & $\begin{array}{c}\text { 16.352**** } \\
(3.786)\end{array}$ & $\begin{array}{c}7.752 * * * \\
(1.365)\end{array}$ & $\begin{array}{c}1.207 * * \\
(0.474)\end{array}$ & $\begin{array}{l}0.171 * \\
(0.094)\end{array}$ \\
\hline Birth Country Dummies & Yes & Yes & Yes & Yes & Yes & Yes & Yes & Yes \\
\hline Individual Controls & Yes & Yes & Yes & Yes & Yes & Yes & Yes & Yes \\
\hline $\mathrm{N}$ & 216 & 216 & 216 & 216 & 452 & 452 & 452 & 452 \\
\hline Adjusted $\mathrm{R}^{2}$ & 0.395 & 0.425 & 0.103 & 0.112 & 0.246 & 0.309 & 0.122 & 0.118 \\
\hline
\end{tabular}

Source: Authors' calculations based on the Gallup World Poll, 2008-2013

Notes: Difference-in-Differences estimation using robust standard errors and the Gallup-provided survey weight. Household income is in 1,000s of international dollars (ID), which allows comparisons across countries and time. The variable "Household Income Per Household Member" is constructed by dividing total household income (in 1,000 ID) by the number of household members. Best Possible Life (BPL) measures the respondent's assessment of her current life relative to her best possible life on a scale of 0 to 10 , where 0 is the worst possible life, and 10 is the best possible life. "Freedom" is binary variable coded as 1 if the respondent is satisfied with his or her freedom to choose in life and as 0 otherwise. The individual control variables include: age, age squared, gender, religion dummies, and education. See Table 2 for the top sending and destination countries.

$* * * \mathrm{p}<0.01, * * \mathrm{p}<0.05, * \mathrm{p}<0.1$ 


\section{Robustness Checks}

\subsection{Matching with Respondents with Emigration Plans}

As a robustness check, we matched migrants in Group 1 with respondents in the source countries with concrete migration plans (as opposed to those expressing willingness to leave in the main analysis sample). We employed the same matching covariates and procedures. Gallup started asking the question about migration plans in 2010, which limits the number of observations. ${ }^{18}$ Therefore, we used a less strict caliper of 0.5 to ensure about 50 observations per group. The sample includes 53 observations per group (212 observations total). Eighteen transition countries are represented, compared with 20 in the main analysis. The top sending countries are Romania, Poland, Bulgaria and Croatia, and the most common host countries are Italy, Germany, and Austria (see table A.1).

Table A.2 demonstrates that the matching produced observably similar migrant and stayer groups. In the "post" period, migrants and non-migrants are on average 42-43 years old, while their counterparts pre-migration are in their early-to-mid thirties. A little under a third of respondents in all groups are college-educated (compared with 18 percent in the main analysis sample). Across the board, about two thirds are female, about a third is Catholic, and 47 percent are Christian Orthodox. Immigrants (Group 1) have the highest household incomes, SWB scores, and are more satisfied with their freedom than any other group. Note, however, that the BPL score of those planning to migrate (Group 2) is very similar to that of immigrants, suggesting that those with concrete emigration plans may receive a life satisfaction boost due to having made the emigration decision. In general, Table A.2. shows that the mean outcomes of migrants and stayers with respect to BPL and freedom perceptions are very similar.

\footnotetext{
${ }^{18}$ Between 2010-2013, about 19 percent of citizens from transition countries expressed a desire to emigrate, only 1.39 percent made emigration plans for the next year, and 0.69 percent prepared for this move.
} 
Table 6 shows the DID results for the robustness check, with Models (1)-(4) presenting the findings without country of birth and individual controls, and Models (5)-(8) adding these covariates. Despite the small sample size, the results are generally robust and similar across the two sets of models. We focus on the results including the full set of controls. First, the income premium from migration is larger than that in the main model and is 29,800 ID (the income premium per household member is about 11,000 ID). The satisfaction with freedom DID is positive but not statistically significant. Moreover, the BPL DID is statistically insignificant. The summary statistics showed that while migrants' evaluative well-being is slightly higher, it is not statistically different from that of the other groups. The freedom perceptions were also similar across groups (Table A.2). These results indicate that migration has a positive causal influence on income, although the evaluative well-being and the freedom gains are statistically insignificant, likely due to the small sample size or the possibility that those with concrete emigration plans have received a life satisfaction boost from making the decision. Experimental findings show that expectations affect hedonic happiness even before the outcomes are revealed and that the expectations related to making decisions affect happiness (Rutledge, et al., 2014). 
Table 6. Analysis Sample, Matching with Those Planning to Move, DID Results

\begin{tabular}{|c|c|c|c|c|c|c|c|c|}
\hline & \multicolumn{4}{|c|}{ Full Sample No Covariates } & \multicolumn{4}{|c|}{ Full Sample With Covariates } \\
\hline & $\begin{array}{c}\text { (1) } \\
\text { Household } \\
\text { Income }\end{array}$ & $\begin{array}{c}(2) \\
\text { HH Income } \\
\text { Per HH } \\
\text { Member } \\
\end{array}$ & (3) & Freedom & $\begin{array}{l}\text { (5) } \\
\text { Household } \\
\text { Income }\end{array}$ & $\begin{array}{c}(6) \\
\text { HH Income } \\
\text { Per HH } \\
\text { Member } \\
\end{array}$ & BPL & Freedom \\
\hline Migrant (1=Yes) & $\begin{array}{l}-0.762 \\
(3.875)\end{array}$ & $\begin{array}{l}-0.117 \\
(1.429)\end{array}$ & $\begin{array}{c}1.071 * * \\
(0.503)\end{array}$ & $\begin{array}{l}-0.123 \\
(0.111)\end{array}$ & $\begin{array}{l}-2.523 \\
(3.898)\end{array}$ & $\begin{array}{l}-0.420 \\
(1.412)\end{array}$ & $\begin{array}{c}0.929 * * \\
(0.416)\end{array}$ & $\begin{array}{l}-0.172 * \\
(0.099)\end{array}$ \\
\hline After Migration ( $1=$ Yes) & $\begin{array}{l}-2.500 \\
(2.540)\end{array}$ & $\begin{array}{l}-0.600 \\
(1.101)\end{array}$ & $\begin{array}{c}0.575 \\
(0.566)\end{array}$ & $\begin{array}{c}0.005 \\
(0.108)\end{array}$ & $\begin{array}{l}-0.398 \\
(3.115)\end{array}$ & $\begin{array}{c}0.698 \\
(1.284)\end{array}$ & $\begin{array}{c}0.648 \\
(0.475)\end{array}$ & $\begin{array}{l}-0.032 \\
(0.100)\end{array}$ \\
\hline Migrant*After & $\begin{array}{c}29.962 * * * \\
(8.114)\end{array}$ & $\begin{array}{c}11.631 * * * \\
(2.950)\end{array}$ & $\begin{array}{c}-0.537 \\
(0.728)\end{array}$ & $\begin{array}{c}0.140 \\
(0.157)\end{array}$ & $\begin{array}{c}29.807 * * * \\
(7.981)\end{array}$ & $\begin{array}{c}11.027 * * * \\
(2.782)\end{array}$ & $\begin{array}{c}-0.510 \\
(0.625)\end{array}$ & $\begin{array}{c}0.164 \\
(0.141)\end{array}$ \\
\hline Birth Country Dummies & No & No & No & No & Yes & Yes & Yes & Yes \\
\hline Individual Controls & No & No & No & No & Yes & Yes & Yes & Yes \\
\hline $\mathrm{N}$ & 212 & 212 & 212 & 212 & 212 & 212 & 212 & 212 \\
\hline Adjusted $\mathrm{R}^{2}$ & 0.190 & 0.215 & 0.027 & 0.001 & 0.285 & 0.336 & 0.192 & 0.129 \\
\hline
\end{tabular}

Source: Authors' calculations based on the Gallup World Poll, 2009-2013

Notes: Difference-in-Differences estimation using robust standard errors and the Gallup-provided survey weight. Household income is in 1,000s of international dollars (ID), which allows comparisons across countries and time. The variable "Household Income Per Household Member" is constructed by dividing total household income (in 1,000 ID) by the number of household members. Best Possible Life (BPL) measures the respondent's assessment of her current life relative to her best possible life on a scale of 0 to 10 , where 0 is the worst possible life, and 10 is the best possible life. "Freedom" is binary variable coded as 1 if the respondent is satisfied with his or her freedom to choose in life and as 0 otherwise. The individual control variables include: age, age squared, gender, religion dummies, and education.

$* * * \mathrm{p}<0.01, * * \mathrm{p}<0.05, * \mathrm{p}<0.1$ 


\subsection{EU-10 Migrants}

Of particular interest to national governments and EU policymakers alike is how migrants from the recent EU enlargements fare in the destination countries. To examine this question, we focus on EU-10 immigrants in the advanced EU countries. ${ }^{19}$ We performed the matching and DID steps again only for this subsample (see Tables A.3-A.4 for the summary statistics). Only Slovakia is not represented among the EU-10 migrants and the top origin countries are Poland, Romania, and Lithuania, and the top destinations are Germany, Spain, and Ireland. Migrants appear to have higher incomes, SWB, and perceptions of freedom in the destination countries (see table A.4).

Table 7 shows the results from this alternative specification. The main results and conclusions still hold, albeit with some nuances. First, while the household earnings premium is still sizeable and statistically significant, it is smaller in magnitude ${ }^{20}$ This is unsurprising as EU10 migrants are leaving countries that are wealthier, on average, than the non-EU transition countries. The SWB benefit from migration is still sizeable - 1.3 on average compared with 1.2 in the main results. There are also sizeable gains in satisfaction with freedom, which are larger than those in the main analysis sample. When Bulgaria and Romania - the poorest and unhappiest EU members - are excluded from the source countries, the household income premium rises to 21,000 ID (12,700 ID per household member), the evaluative well-being gain is 1.8 , and satisfaction with freedom increases by 44 percent on average. ${ }^{21}$

\footnotetext{
${ }^{19}$ See footnote 4 for the list of transition countries that are EU members. Croatia is excluded from the sending countries as it only joined the EU in 2013. The advanced EU countries include the EU-15 and Malta and Cyprus.

${ }^{20}$ The earnings premium per household member of 9,100 ID is similar to that in the main sample (10,500 ID).

${ }^{21}$ Results available upon request.
} 
Table 7. EU Sample, DID Results

\begin{tabular}{|c|c|c|c|c|c|c|c|c|}
\hline & \multicolumn{4}{|c|}{ Full Sample No Covariates } & \multicolumn{4}{|c|}{ Full Sample With Covariates } \\
\hline & $\begin{array}{c}\text { (1) } \\
\text { Household } \\
\text { Income }\end{array}$ & $\begin{array}{c}(2) \\
\text { HH Income } \\
\text { Per HH } \\
\text { Member } \\
\end{array}$ & $\begin{array}{r}\text { (3) } \\
\text { BPL } \\
\end{array}$ & Freedom & $\begin{array}{l}\text { (5) } \\
\text { Household } \\
\text { Income }\end{array}$ & $\begin{array}{c}(6) \\
\text { HH Income } \\
\text { Per HH } \\
\text { Member } \\
\end{array}$ & BPL & Freedom \\
\hline Migrant (1=Yes) & $\begin{array}{c}1.775 \\
(2.351)\end{array}$ & $\begin{array}{c}0.133 \\
(0.896)\end{array}$ & $\begin{array}{l}-0.675^{*} \\
(0.401)\end{array}$ & $\begin{array}{l}-0.124 \\
(0.088)\end{array}$ & $\begin{array}{c}1.092 \\
(1.959)\end{array}$ & $\begin{array}{l}-0.256 \\
(0.727)\end{array}$ & $\begin{array}{l}-0.687 * \\
(0.363)\end{array}$ & $\begin{array}{l}-0.135 \\
(0.084)\end{array}$ \\
\hline $\begin{array}{l}\text { After Migration } \\
(1=\text { Yes })\end{array}$ & $\begin{array}{c}1.508 \\
(2.019)\end{array}$ & $\begin{array}{c}0.146 \\
(0.765)\end{array}$ & $\begin{array}{c}-0.085 \\
(0.440)\end{array}$ & $\begin{array}{l}-0.035 \\
(0.087)\end{array}$ & $\begin{array}{c}1.144 \\
(2.069)\end{array}$ & $\begin{array}{l}-0.255 \\
(0.749)\end{array}$ & $\begin{array}{c}0.076 \\
(0.428)\end{array}$ & $\begin{array}{l}-0.020 \\
(0.085)\end{array}$ \\
\hline Migrant*After & $\begin{array}{c}15.475 * * * \\
(5.055)\end{array}$ & $\begin{array}{l}9.172 * * * \\
(2.010)\end{array}$ & $\begin{array}{c}1.432 * * \\
(0.572)\end{array}$ & $\begin{array}{c}0.377 * * * \\
(0.116)\end{array}$ & $\begin{array}{c}14.866 * * * \\
(4.180)\end{array}$ & $\begin{array}{c}9.093 * * * \\
(1.718)\end{array}$ & $\begin{array}{c}1.325 * * \\
(0.546)\end{array}$ & $\begin{array}{c}0.354 * * * \\
(0.113)\end{array}$ \\
\hline $\begin{array}{l}\text { Birth Country } \\
\text { Dummies }\end{array}$ & No & No & No & No & Yes & Yes & Yes & Yes \\
\hline Individual Controls & No & No & No & No & Yes & Yes & Yes & Yes \\
\hline $\mathrm{N}$ & 316 & 316 & 316 & 316 & 316 & 316 & 316 & 316 \\
\hline Adjusted $\mathrm{R}^{2}$ & 0.132 & 0.189 & 0.037 & 0.064 & 0.276 & 0.326 & 0.096 & 0.110 \\
\hline
\end{tabular}

Source: Authors' calculations based on the Gallup World Poll, 2008-2013

Notes: Difference-in-Differences estimation using robust standard errors and the Gallup-provided survey weight. Household income is in 1,000s of international dollars (ID), which allows comparisons across countries and time. The variable "Household Income Per Household Member" is constructed by dividing total household income (in 1,000 ID) by the number of household members. Best Possible Life (BPL) measures the respondent's assessment of her current life relative to her best possible life on a scale of 0 to 10 , where 0 is the worst possible life, and 10 is the best possible life. "Freedom" is binary variable coded as 1 if the respondent is satisfied with his or her freedom to choose in life and as 0 otherwise. The individual control variables include: age, age squared, gender, religion dummies, and education.

$* * * \mathrm{p}<0.01, * * \mathrm{p}<0.05, * \mathrm{p}<0.1$ 


\subsection{Return Migration}

Return migration poses a validity threat as it is possible that because of the economic crisis or some other circumstances, those with the lowest SWB, satisfaction with freedom, and/or the least skilled immigrants returned back to their home countries. ${ }^{22}$ Return migration may also be undertaken to correct errors in the initial migration decision or because the migrant has acquired human capital valued at home (Borjas, 2014). While not causal, research finds that Romanian returnees are unhappier than stayers (Bartram, 2012).

While GWP does not explicitly inquire about return migration, two questions could be used to shed some light: (i) whether respondents have lived in a foreign country for more than six months (asked in 2009-2012 in all transition economies except Mongolia) and (ii) whether the respondent went abroad in the past five years to make money (asked in 2007 in several transition economies). We do not have information on the country of residence prior to return, duration of stay, or reason for return. However, a follow-up question specifically asks respondents whether their social status increased, fell, or did not change as a result of going abroad to make money in the past five years. Of the 624 respondents who gave valid answers to this question, social status fell for about a third (34 percent) and did not change for about 43 percent.

To examine whether return migration biases our results, we matched returnees in transition economies (the treatment group) with immigrants from transition countries still living in the advanced countries (the controls). We used PSM and the following matching covariates: age, age squared, religion, education, country of birth, and year. We forced exact matching by

\footnotetext{
${ }^{22}$ There have been no large outflows of migrants due to the economic crisis as migrants may actually be unwilling to return to their home countries because they fear barriers to coming back or dread bleak job prospects at home (Awad, 2009; Fix et al., 2009; Green \& Winters, 2010).
} 
country of birth and year. When "Went Abroad to Make Money" is the treatment variable, religion and year are excluded from the matching covariates due to missing observations and the fact that the data are for 2007 only, respectively. ${ }^{23}$

We used nearest neighbor matching without replacement with two calipers -0.01 and 0.001 (see table 8), which provides results that generally satisfy the balancing property (tables A.5-A.7). The results suggest that return migration is associated with lower incomes and SWB (BPL) regardless of the matching procedure and the treatment variable used. Taken at face value, the results in Table 8 imply that the household income penalty due to return migration is between 14,500 and 18,700 ID, depending on the model, while BPL declines are between 0.7 and 1.7. The results regarding satisfaction with freedom are not robust, however.

These results should be treated with caution as we do not know whether the lower earnings and SWB are because of return migration or because of selection issues. In this instance, total bias reduction is impossible as we cannot include a large number of covariates (due the restriction that the treatment cannot influence the matching variables). Thus, while return migration may be a validity threat, it is unlikely that it is driving all the results in this paper.

\footnotetext{
${ }^{23}$ While return migration as a result of the crisis has been limited, there have been returns from Russia to Tajikistan, Uzbekistan, and Kyrgyzstan (Green \& Winters, 2010), Poles returning from the UK, and some forceful deportations from the US, Italy, and France, including those of Bulgarian and Romanian Roma from France (Papademetriou, Sumption, Terrazas, Loyal, \& Ferrero-Turrión, 2010). There is little information on the demographic profile of those who left, however.
} 
Table 8. Return Migration and Well-being, Average Treatment Effect using Propensity Score Matching

Treatment: Lived Abroad for More than 6 Months; Nearest Neighbor Matching without replacement, caliper=0.01

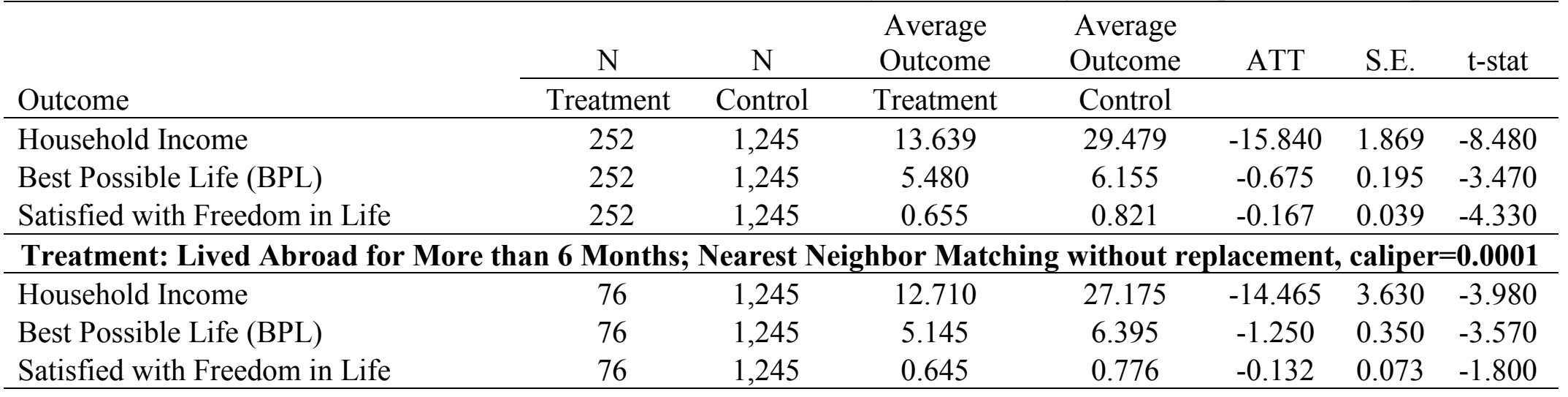

\begin{tabular}{lcccccccc}
\hline \multicolumn{7}{c}{ Treatment: Went Abroad to Make Money; Nearest Neighbor Matching without replacement, caliper=0.01 } \\
\hline & & & Average & Average & & \\
& $\mathrm{N}$ & $\mathrm{N}$ & Outcome & Outcome & ATT & S.E. & t-stat \\
\cline { 2 - 8 } Outcome & Treatment & Control & Treatment & Control & & & \\
\hline Household Income & 42 & 700 & 10.042 & 28.732 & -18.690 & 2.967 & -6.300 \\
Best Possible Life (BPL) & 42 & 700 & 5.405 & 7.143 & -1.738 & 0.422 & -4.110 \\
Satisfied with Freedom in Life & 42 & 700 & 0.595 & 0.762 & -0.167 & 0.101 & -1.640 \\
\hline
\end{tabular}

Source: Authors' calculations based on the Gallup World Poll.

Notes: ATT=Average Treatment Effect. The data are for 2009-2012 when the treatment is whether the respondent lived abroad for more than 6 months, and for 2007 when the treatment is whether the respondent went abroad in the past 5 years to make money. Summary of results from propensity score matching. $\mathrm{N}$ refers to the number of observations in the common support region. The treatment group is return migrants. The control group is immigrants from transition economies in advanced countries. The matching variables include: age, age squared, religion, education, country of birth, and year. We force exact matching by country of birth and year (year is excluded when the treatment is "Went Abroad to Make Money").

When "Went Abroad to Make Money" is the treatment variable, religion and year are excluded from the matching covariates. Household income is in 1,000 s of international dollars (ID), which allows comparisons across countries and time. Best Possible Life (BPL) measures the respondent's assessment of her current life relative to her best possible life on a scale of 0 to 10 , where 0 is the worst possible life, and 10 is the best possible life. "Freedom" is binary variable coded as 1 if the respondent is satisfied with his or her freedom to choose in life and as 0 otherwise. Balancing tests available in Tables A.5-A.7. 


\section{Channels}

This paper's empirical strategy explicitly allows us to explore the well-being consequences of migration but not the pathways leading to them. Theoretically, several mechanisms could be enhancing the well-being of migrants from transition economies. As the channels affecting income are straightforward, we focus on the SWB and freedom dimensions.

First, migration could enhance SWB through the positive income gains. For example, Olgiati, Calvo, and Berkman (2013) show that income is associated with higher global life evaluation and life satisfaction among immigrants in 16 advanced countries. Moreover, income and SWB are positively correlated in transition economies (Easterlin, 2009). In addition, CEE migrants move to the EU-15 for employment (Kahanec, 2013). Therefore, they likely migrate because of better employment and income opportunities and freedoms, which may also enhance their SWB. The consistently positive effect on the satisfaction with freedom outcome in this paper highlights this channel.

Second, while the majority of the studies find a negative association between happiness and migration, the results depend on country of origin (Simpson, 2014). Research using GWP data shows that North-to-North migrants experience gains in various perceived well-being dimensions, unlike migrants moving from other contexts (Esipova et al., 2013). The countries from which the migrants in this paper moved are relatively advanced and culturally similar to the destination countries, which likely facilitates their assimilation and adaptation.

Third, there are several mechanisms that could also decrease migrant SWB. Psychological distress from separation from one's family and friends (i.e., loss of social capital), culture shock, loss of cultural identity, changing reference norms, and rising expectations likely 
lower the perceived well-being of migrants. While these same issues are also likely to affect migrants from transition economies to the EU, they face far fewer barriers to returning to their home countries to visit than, for example, South-to-North migrants. Finally, time-use data on migrants from Central and Eastern Europe living in the UK and New Jersey demonstrate that immigrant men spent much time working and limited time with their families and immigrant women from Poland spent much time working in low-skilled jobs and less time socializing, leading to isolation (Ribar, 2013). Despite these opposite effects of migration on SWB, it seems that the positive channels dominate in this analysis sample.

\section{Limitations}

We acknowledge several limitations. First, despite the use of matching and DID, our results could suffer from selection bias. While movers and stayers are similar based on observable characteristics, a non-experimental technique cannot fully address selection bias from unobservables. Although we match on education, which is a proxy for ability, unobservable factors such as motivation and skills likely positively bias our results. While we cannot provide a precise estimate of the size of this bias, one study's findings imply that the migration gains we find are likely overstated by at least about 20 percent (McKenzie et al., 2010). ${ }^{24}$

Second, while our empirical strategy explicitly addresses selection, it does not deal with endogeneity. Since we only have cross-sectional data, we cannot establish whether the positive well-being effects are because of migration or because respondents with greater a priori wellbeing are more likely to migrate. The research shows, however, that lower levels of life satisfaction are correlated with the migration decision for migrants from transition economies (Otrachshenko \& Popova, 2014) and Latin America (Graham and Markowitz, 2011). The SWB gains from migration, therefore, are unlikely to be due to the positive SWB selection of migrants.

\footnotetext{
${ }^{24}$ Moreover, the empirical strategy is based on assumptions, some of which are untestable.
} 
Third, since GWP is not specifically designed to study migrants, it has several limitations. GWP does not distinguish between voluntary and involuntary migrants, lacks information on year of arrival in the destination country and detailed information on return migration, which is problematic. Due to the limited number of observations, we do not distinguish between migrants who arrived in the host country in the past five years or later. Since the majority of immigrants are established, they could have simply adapted to living in the destinations. Fourth, caution is necessary when extrapolating these results to other countries and contexts. The well-being effects of migration likely differ depending on the migrant cohort studied, the destination countries, and the well-being metrics employed.

\section{Policy Implications and Conclusion}

This study asked whether migration improves the well-being of immigrants from transition economies who moved to advanced economies. Using cross-sectional data from the Gallup World Poll (GWP) and a methodology combining statistical matching with difference-indifferences, we show that migration enhances well-being. The mean household earnings premium is about 21,000 ID and the average life satisfaction benefit is about 1.0 -1.2 on a scale of 0-10. Movers from the EU-10 to the rest of the EU realize even larger SWB gains of up to 1.4 (1.8 when we exclude Bulgarians and Romanians). Moreover, migration increases freedom satisfaction by about 26-28 percent on average. The results are generally robust to several robustness checks.

The "happiness and migration" literature suggests that increases in income post-migration may be accompanied by declining happiness because of adaptation and rising aspirations. While migrants' (absolute) incomes increase, so do their expectations as they compare themselves to high-earning natives in the host countries. We find, however, that migrants from transition 
countries are in fact happier after they go abroad. This suggests that even if their reference norms and aspirations change, movers' objective and subjective quality of life improves post-migration. The relevance of these results for immigrants from other world regions is an empirical question for future research.

Although migration may have positive well-being effects while also allowing movers to escape the opportunity constraints at home, it is not a comprehensive development strategy. It does not solve deeply-rooted social problems such as corruption, misguided economic policies, and other market and government failures in the sending countries (De Haas, 2010). And while it may enhance individual well-being and autonomy, as we find, it may have negative consequences for the happiness of family members left behind (Borraz, Pozo, \& Rossi, 2010; Jones, 2014). Future research is needed to understand if migration can enhance individual wellbeing without negative effects on the "common good" in the sending countries. 


\section{References}

Abadie, A. (2005). Semiparametric Difference-in-Differences Estimators. The Review of Economic Studies, 72(1), 1-19.

Abramitzky, R., Boustan, L. P., \& Eriksson, K. (2012). Europe's Tired, Poor, Huddled Masses: Self-Selection and Economic Outcomes in the Age of Mass Migration. American Economic Review, 102(5), 1832-1856.

Ai, C., \& Norton, E. C. (2003). Interaction Terms in Logit and Probit Models. Economics Letters, 80(1), 123-129.

Akay, A., Constant, A., \& Giulietti, C. (2014). The Impact of Immigration on the Well-Being of Natives. Journal of Economic Behavior \& Organization, 103, 72-92.

Amit, K. (2010). Determinants of Life Satisfaction among Immigratns from Western Countries and from the FSU in Israel. Social Indicators Research, 96(3), 515-534.

Amit, K., \& Litwin, H. (2010). The Subjective Well-Being of Immigrants Aged 50 and Older in Israel. Social Indicators Research, 98(1), 89-104.

Awad, I. (2009). The Global Economic Crisis and Migrant Workers: Impact and Response. Geneva, Switzerland: International Migration Programme, International Labour Organization.

Baltatescu, S. (2007). Central and Eastern Europeans Migrants' Subjective Quality of Life. A Comparative Study. Journal of Identity and Migration Studies, 1(2), 67-81.

Bartram, D. (2010). International Migration, Open Borders Debates, and Happiness. International Studies Review, 12(3), 339-361.

Bartram, D. (2011). Economic Migration and Happiness: Comparing Immigrants' and Natives' Happiness Gains from Income. Social Indicators Research, 103(1), 57-76.

Bartram, D. (2013). Happiness and 'Economic Migration': A Comparison of Eastern European Migrants and Stayers. Migration Studies, 1(2), 156-175.

Bartram, D. (2014). Inverting the Logic of Economic Migration: Happiness among Migrants Moving from Wealthier to Poorer Countries in Europe. Journal of Happiness Studies, 120, forthcoming.

Bauer, T. K., Epstein, G. S., \& Gang, I. N. (2000). What Are Migration Networks? IZA DP No. 200. 
Beine, M. A., \& Parsons, C. R. (2012). Climatic Factors as Determinants of International Migration: IRES de l'Université Catholique de Louvain Discussion Paper 2012-2, Louvain-la-Neuve, Belgium.

Bertocchi, G., \& Strozzi, C. (2008). International Migration and the Role of Institutions. Public Choice, 137(1-2), 81-102.

Betz, W., \& Simpson, N. B. (2013). The Effects of International Migration on the Well- Being of Native Populations in Europe. IZA Journal of Migration, 2(12), 1-21.

Bhagwati, J., \& Hamada, K. (1974). The Brain Drain, International Integration of Markets for Professionals and Unemployment: A Theoretical Analysis. Journal of Development Economics, 1(1), 19-42.

Blanchflower, D. G., \& Shadforth, C. (2009). Fear, Unemployment and Migration. The Economic Journal, 119(535), F136-F182.

Blundell, R., \& Costa Dias, M. (2000). Evaluation Methods for Non-Experimental Data. Fiscal Studies, 21(4), 427-468.

Borjas, G. J. (1987). Self-Selection and the Earnings of Immigrants. American Economic Review, 77(4), 531-553.

Borjas, G. J. (1994). The Economics of Immigration. Journal of Economic Literature, XXXII, $1667-1717$.

Borjas, G. J. (2001). Heaven's Door: Immigration Policy and the American Economy. Princeton, NJ: Princeton University Press.

Borjas, G. J. (2014). Immigration Economics. Cambridge, MA: Harvard University Press.

Borraz, F., Pozo, S., \& Rossi, M. (2010). And What About the Family Back Home? International Migration and Happiness in Cuenca, Ecuador. Journal of Business Strategies, 27(1).

Cai, R., Esipova, N., Oppenheimer, M., \& Feng, S. (2014). International Migration Desires Related to Subjective Well-Being. IZA Journal of Migration, 3(1), 1-20.

Caliendo, M., \& Kopeinig, S. (2008). Some Practical Guidance for the Implementation of Propensity Score Matching. Journal of Economic Surveys, 22(1), 31-72.

Cantril, H. (1965). Pattern of Human Concerns: New Brunswick, NJ: Rutgers University Press.

Card, D. (2005). Is the New Immigration Really So Bad? The Economic Journal, 115(507), F300-F323. 
Chindarkar, N. (2014). Is Subjective Well-Being of Concern to Potential Migrants from Latin America? Social Indicators Research, 115(1), 159-182.

Clemens, M. A., \& Bazzi, S. (2008). Don't Close the Golden Door: Our Noisy Debate on Immigration and Its Deathly Silence on Development. Center for Global Development Essay.

Clemens, M. A., Montenegro, C. E., \& Pritchett, L. (2008). The Place Premium: Wage Differences for Identical Workers across the Us Border. World Bank Policy Research Working Paper No. 4671.

Creighton, M. J. (2013). The Role of Aspirations in Domestic and International Migration. The Social Science Journal, 50(1), 79-88.

Czaika, M., \& de Haas, H. (2012). The Role of Internal and International Relative Deprivation in Global Migration. Oxford Development Studies, 40(4), 423-442.

Czaika, M., \& Vothknecht, M. (2014). Migration and Aspirations - Are Migrants Trapped on a Hedonic Treadmill? IZA Journal of Migration, 3(1), 1-21.

Danzer, A. M., \& Dietz, B. (2014). Labour Migration from Eastern Europe and the EU's Quest for Talents. JCMS: Journal of Common Market Studies, 52(2), 183-199.

De Haas, H. (2010). Migration and Development: A Theoretical Perspective. International Migration Review, 44(1), 227-264.

De Haas, H. (2011). The Determinants of International Migration. IMI/DEMIG working paper, International Migration Institute, University of Oxford.

De Jong, G. F., Chamratrithirong, A., \& Tran, Q.-G. (2002). For Better, for Worse: Life Satisfaction Consequences of Migration. International Migration Review, 36(3), 838-863.

De Neve, J.-E., Diener, E., Tay, L., \& Xuereb, C. (2013). The Objective Benefits of Subjective Well-Being. In J. F. Helliwell, R. Layard \& J. Sachs (Eds.), World Happiness Report (pp. 54-79).

De Neve, J.-E., \& Oswald, A. J. (2012). Estimating the Influence of Life Satisfaction and Positive Affect on Later Income Using Sibling Fixed Effects. Proceedings of the National Academy of Sciences, 109(49), 19953-19958.

Dehejia, R. H., \& Wahba, S. (2002). Propensity Score-Matching Methods for Nonexperimental Causal Studies. Review of Economics and Statistics, 84(1), 151-161.

Deneulin, S. (2006). Individual Well-Being, Migration Remittances and the Common Good. The European Journal of Development Research, 18(1), 45-58. 
Di Tella, R., \& MacCulloch, R. (2006). Some Uses of Happiness Data in Economics. The Journal of Economic Perspectives, 20(1), 25-46.

Di Tella, R., MacCulloch, R. J., \& Oswald, A. J. (2001). Preferences over Inflation and Unemployment: Evidence from Surveys of Happiness. The American Economic Review, 91(1), 335-341.

Diener, E., Inglehart, R., \& Tay, L. (2013). Theory and Validity of Life Satisfaction Scales. Social Indicators Research, 112(3), 497-527.

Diener, E., Suh, E. M., Lucas, R. E., \& Smith, H. L. (1999). Subjective Well-Being: Three Decades of Progress. Psychological Bulletin, 125(2), 276-302.

Dolan, P., Peasgood, T., \& White, M. (2008). Do We Really Know What Makes Us Happy? A Review of the Economic Literature on the Factors Associated with Subjective WellBeing. Journal of Economic Psychology, 29(1), 94-122.

Durand, M., \& Smith, C. (2013). The Oecd Approach to Measuring Subjective Well-Being. In J. Helliwell, R. Layard \& J. Sachs (Eds.), World Happiness Report (pp. 112-137).

Dustmann, C., \& Okatenko, A. (2014). Out-Migration, Wealth Constraints, and the Quality of Local Amenities. Journal of Development Economics, 110(0), 52-63.

Dustmann, C., Frattini, T., \& Halls, C. (2010). Assessing the Fiscal Costs and Benefits of A8 Migration to the UK. Fiscal Studies, 31(1), 1-41.

Easterlin, R. A. (1974). Does Economic Growth Improve the Human Lot? Some Empirical Evidence. In P. David and M. Reder (Ed.), Nations and Households in Economic Growth: Essays in Honour of Moses Abramovitz (pp. 89-125). New York, NY: Academic Press.

Easterlin, R. A. (2009). Lost in Transition: Life Satisfaction on the Road to Capitalism. Journal of Economic Behavior \& Organization, 71(2), 130-145.

Ek, E., Koiranen, M., Raatikka, V.-P., Järvelin, M.-R., \& Taanila, A. (2008). Psychosocial Factors as Mediators between Migration and Subjective Well-Being among Young Finnish Adults. Social Science \& Medicine, 66(7), 1545 - 1556.

Erlinghagen, M. (2012). Nowhere Better Than Here? The Subjective Well-Being of German Emigrants and Remigrants. Comparative Population Studies, 36(4), 899-926.

Esipova, N., Pugliese, A., Ray, J., \& Kanitkar, K. (2013). Dimensions of Migrant Well-Being: Evidence from the Gallup World Poll. International Organization for Migration. World 
Migration Report 2013: Migrant Well-Being and Development (pp. 104-171): International Migration Organization.

Ferrer-i-Carbonell, A., \& Frijters, P. (2004). How Important Is Methodology for the Estimates of the Determinants of Happiness?. The Economic Journal, 114(497), 641-659.

Fix, M., Papademetriou, D. G., Batalova, J., Terrazas, A., Lin, S. Y.-Y., \& Mittelstadt, M. (2009). Migration and the Global Recession: A Report Commissioned by the BBC World Service. Washington, DC: Migration Policy Institute.

Frijters, P., \& Beatton, T. (2012). The Mystery of the U-Shaped Relationship between Happiness and Age. Journal of Economic Behavior \& Organization, 82(2), 525-542.

Graham, C. (2009). Happiness around the World: The Paradox of Happy Peasants and Miserable Millionaires. Oxford: Oxford University Press.

Graham, C. (2011). The Pursuit of Happiness: An Economy of Well-Being. Washington, DC: The Brookings Institution Press.

Graham, C. (2012). The Distinctiveness of Hedonic and Evaluative Well-Being. Notes Prepared for the National Academies of Science (NAS) Panel. Washington, DC: The Brookings Institution.

Graham, C., Eggers, A., \& Sukhtankar, S. (2004). Does Happiness Pay?: An Exploration Based on Panel Data from Russia. Journal of Economic Behavior \& Organization, 55(3), 319342.

Graham, C., \& Markowitz, J. (2011). Aspirations and Happiness of Potential Latin American Immigrants. Journal of Social Research \& Policy, 2(2), 9-25.

Green, T., \& Winters, L. A. (2010). Economic Crises and Migration: Learning from the Past and the Present. The World Economy, 33(9), 1053-1072.

Grether, J.-M., De Melo, J., \& Müller, T. (2001). The Political Economy of International Migration in a Ricardo-Viner Model. CEPR Discussion Paper 2714.

Hanson, G. H. (2010). International Migration and the Developing World. In D. Rodrik \& M. Rosenzweig (Eds.), Handbook of Development Economics (Vol. 5, pp. 4363-4414).

Hatton, T. J., \& Williamson, J. G. (2002). What Fundamentals Drive World Migration? : National Bureau of Economic Research.

Heinrich, C., Maffioli, A., \& Vazquez, G. (2010). A Primer for Applying Propensity-Score Matching: Impact-Evaluation Guidelines. Office of Strategic Planning and Development Effectiveness, Inter-American Development Bank, 1-56. 
Helliwell, J. F., \& Barrington-Leigh, C. P. (2010). Viewpoint: Measuring and Understanding Subjective Well-Being. Canadian Journal of Economics, 43(3), 729-753.

Helliwell, J. F., Barrington-Leigh, C. P., Harris, A., \& Huang, H. (2010). International Evidence on the Social Context of Well-Being. In J. F. Helliwell. E. Diener, and D. Kahneman (Eds.), International Differences in Well-Being. New York, NY: Oxford University Press.

IMF. (2014). World Economic Outlook April 2014: Recover Stenghtens, Remains Uneven. Washington, DC: International Monetary Fund.

Ivlevs, A. (2014). Happy Moves? Assessing the Impact of Subjective Well-Being on the Emigration Decision. University of the West of England Economics Working Paper Series 1402, 1-23.

Ivlevs, A., \& King, R. M. (2012a). Does More Schooling Make You Run for the Border? Evidence from Post-Independence Kosovo. The Journal of Development Studies, 48(8), 1108-1120.

Ivlevs, A., \& King, R. M. (2012b). Family Migration Capital and Migration Intentions. Journal of Family and Economic Issues, 33(1), 118-129.

Jones, R. C. (2014). Migration and Family Happiness in Bolivia: Does Social Disintegration Negate Economic Well-Being? International Migration, 52(3), 177-193.

Kahanec, M. (2013). Labor Mobility in and Enlarged European Union. In A. F. Constant \& K. F. Zimmermann (Eds.), International Handbook on the Economics of Migration (pp. 137152). Northampton, MA: Edward Elgar Publishing Limited.

Kahneman, D., \& Deaton, A. (2010). High Income Improves Evaluation of Life but Not Emotional Well-Being. Proceedings of the National Academy of Sciences, 107(38), 16489-16493.

Kahneman, D., \& Krueger, A. B. (2006). Developments in the Measurement of Subjective WellBeing. Journal of Economic Perspectives, 20(1), 3-24.

Kahneman, D., Wakker, P. P., \& Sarin, R. (1997). Back to Bentham? Explorations of Experienced Utility. The Quarterly Journal of Economics, 112(2), 375-406.

Knight, J., \& Gunatilaka, R. (2010). Great Expectations? The Subjective Well-Being of RuralUrban Migrants in China. World Development, 38(1), 113 - 124.

Leuven, E., \& Sianesi, B. (2003). Psmatch2: Stata Module to Perform Full Mahalanobis and Propensity Score Matching, Common Support Graphing, and Covariate Imbalance Testing. Statistical Software Components; Boston College Department of Economics. 
Massey, D. S., Arango, J., Hugo, G., Kouaouci, A., Pellegrino, A., \& Taylor, J. E. (1993). Theories of International Migration: A Review and Appraisal. Population and Development Review, 19(3), 431-466.

Mayda, A. M. (2010). International Migration: A Panel Data Analysis of the Determinants of Bilateral Flows. Journal of Population Economics, 23(4), 1249-1274.

Mayer, T., \& Zignago, S. (2011). Notes on CEPII's Distances Measures: The Geodist Database. CEPII Working Paper. Available at: http://www.cepii.fr/CEPII/en/publications/wp/abstract.asp?NoDoc=3877

McKenzie, D., Gibson, J., \& Stillman, S. (2013). A Land of Milk and Honey with Streets Paved with Gold: Do Emigrants Have over-Optimistic Expectations About Incomes Abroad? Journal of Development Economics, 102(0), 116-127.

McKenzie, D., Stillman, S., \& Gibson, J. (2010). How Important Is Selection? Experimental Vs Non-Experimental Measures of Income Gains from Migration. Journal of the European Economic Association, 8(4), 913-945.

Melzer, S. (2011). Does Migration Make You Happy? The Influence of Migration on Subjective Well-Being. Journal of Social Research \& Policy, 2(2), 73-92.

Morawetz, D., Atia, E., Bin-Nun, G., Felous, L., Gariplerden, Y., Harris, E., et al. (1977). Income Distribution and Self-Rated Happiness: Some Empirical Evidence. The Economic Journal, 87(347), pp. 511-522.

Ng, Y.-K. (1996). Happiness Surveys: Some Comparability Issues and an Exploratory Survey Based on Just Perceivable Increments. Social Indicators Research, 38(1), 1-27.

Ng, Y.-K. (1997). A Case for Happiness, Cardinalism, and Interpersonal Comparability. The Economic Journal, 107(445), 1848-1858.

OECD. (2008). A Profile of Immigrant Populations in the 21st Century. Data from OECD Countries. Available at: http://www.oecd.org/fr/els/mig/aprofileofimmigrantpopulationsinthe21stcenturydatafrom oecdcountries.htm

OECD. (2011). How's Life?: Measuring Well-Being: OECD Publishing, http://dx.doi.org/10.1787/9789264121164-en.

OECD. (2013). International Migration Outlook 2013, OECD Publishing. Retrieved from Doi:10.1787/Migr_Outlook-2013-En

Olgiati, A., Calvo, R., \& Berkman, L. (2013). Are Migrants Going up a Blind Alley? Economic Migration and Life Satisfaction around the World: Cross-National Evidence from Europe, North America and Australia. Social Indicators Research, 114(2), 383-404. 
Ortega, F., \& Peri, G. (2009). The Causes and Effects of International Migrations: Evidence from OECD Countries 1980-2005. Washington, DC: National Bureau of Economic Research.

Oswald, A. J. (1997). Happiness and Economic Performance. The Economic Journal, 107(445), 1815-1831.

Oswald, A. J., Proto, E., \& Sgroi, D. (2009). Happiness and Productivity. IZA Discussion Paper No. $4645,1-51$.

Otrachshenko, V., \& Popova, O. (2014). Life (Dis) Satisfaction and the Intention to Migrate: Evidence from Central and Eastern Europe. The Journal of Socio-Economics, 48(0), 4049.

Ottaviano, G. I. P., \& Peri, G. (2012). Rethinking the Effect of Immigration on Wages. Journal of the European Economic Association, 10(1), 152-197.

Papademetriou, D. G., Sumption, M., Terrazas, A., Loyal, C. B. S., \& Ferrero-Turrión, R. (2010). Migration and Immigrants Two Years after the Financial Collapse: Where Do We Stand? Washington, DC: Migration Policy Institute.

Papapanagos, H., \& Sanfey, P. (2001). Intention to Emigrate in Transition Countries: The Case of Albania. Journal of Population Economics, 14(3), 491-504.

Peikes, D. N., Moreno, L., \& Orzol, S. M. (2008). Propensity Score Matching. The American Statistician, 62(3), 222-231.

Ribar, D. C. (2013). Immigrants' Time Use: A Survey of Methods and Evidence. In A. F. Constant \& K. F. Zimmermann (Eds.), International Handbook on the Economics of Migration (pp. 373-392). Northampton, MA: Edward Elgar Publishing Limited.

Rosenbaum, P. R., \& Rubin, D. B. (1983). The Central Role of the Propensity Score in Observational Studies for Causal Effects. Biometrika, 70(1), 41-55.

Rutledge, R. B., Skandali, N., Dayan, P., \& Dolan, R. J. (2014). A Computational and Neural Model of Momentary Subjective Well-Being. Proceedings of the National Academy of Sciences.

Safi, M. (2010). Immigrants' Life Satisfaction in Europe: Between Assimilation and Discrimination. European Sociological Review, 26(2), 159-176.

Sandi, M., \& Winters, L. A. (2014). Migration in the Time of Crisis: Evidence on Its Effectiveness from Indonesia. Mimeo. 
Sen, A. (2000). Social Exclusion: Concept, Application, and Scrutiny. Social Development Papers No. 1, Office of Environment and Social Development Asian Development Bank, $1-54$.

Senik, C. (2011). The French Unhappiness Puzzle: The Cultural Dimension of Happiness. IZA Working Paper No. 6175.

Shadish, W. R., Clark, M. H., \& Steiner, P. M. (2008). Can Nonrandomized Experiments Yield Accurate Answers? A Randomized Experiment Comparing Random and Nonrandom Assignments. Journal of the American Statistical Association, 103(484), 1334-1344.

Shadish, W. R., \& Steiner, P. M. (2010). A Primer on Propensity Score Analysis. Newborn and Infant Nursing Reviews, 10(1), 19-26.

Simpson, N. (2014). Happiness and Migration. In K. F. Zimmermann \& A. F. Constant (Eds.), International Handbook on the Economics of Migration: Edward Elgar Publishing Limited.

Smith, J. A., \& Todd, P. A. (2005). Does Matching Overcome Lalonde's Critique of Nonexperimental Estimators? Journal of Econometrics, 125(1), 305-353.

Stark, O., Micevska, M., \& Mycielski, J. (2009). Relative Poverty as a Determinant of Migration: Evidence from Poland. Economics Letters, 103(3), 119-122.

Stark, O., \& Taylor, J. E. (1989). Relative Deprivation and International Migration. Demography, 26(1), 1-14.

Stark, O., \& Wang, Y. (2002). Inducing Human Capital Formation: Migration as a Substitute for Subsidies. Journal of Public Economics, 86(1), 29 - 46.

Steiner, P. M., Cook, T. D., \& Shadish, W. R. (2011). On the Importance of Reliable Covariate Measurement in Selection Bias Adjustments Using Propensity Scores. Journal of Educational and Behavioral Statistics, 36(2), 213-236.

Steiner, P. M., Cook, T. D., Shadish, W. R., \& Clark, M. (2010). The Importance of Covariate Selection in Controlling for Selection Bias in Observational Studies. Psychological Methods, 15(3), 250.

Stiglitz, J., Sen, A., \& Fitoussi, J.-P. (2009). The Measurement of Economic Performance and Social Progress Revisited. Reflections and overview. Commission on the Measurement of Economic Performance and Social Progress, Paris.

Stillman, S., Gibson, J., McKenzie, D., \& Rohorua, H. (2015). Miserable Migrants? Natural Experiment Evidence on International Migration and Objective and Subjective WellBeing. World Development, 65(0), 79-93. 
Stone, A. A., \& Mackie, C. (2014). Subjective Well-Being: Measuring Happiness, Suffering, and Other Dimensions of Experience. Washignton, DC: National Academies Press.

Stuart, E. A. (2010). Matching Methods for Causal Inference: A Review and a Look Forward. Statistical Ccience: a Review Journal of the Institute of Mathematical Statistics, 25(1), 121.

Tinbergen, J. (1991). On the Measurement of Welfare. Journal of Econometrics, 50(1-2), 7-13.

Todd, P. (2006). Matching Estimators. Retrieved December 16, 2013, from http://athena.sas.upenn.edu/ petra/papers/mpalgrave2.pdf

UN. (2002). International Migration from Countries with Economies in Transition : 1980-1999: Population Division Department of Economic and Social Affairs United Nations Secretariat.

van Dalen, H. P., \& Henkens, K. (2008). Emigration Intentions: Mere Words or True Plans? Explaining International Migration Intentions and Behavior (Discussion Paper): Tilburg University, Center for Economic Research.

van Dalen, H. P., \& Henkens, K. (2013). Explaining Emigration Intentions and Behaviour in the Netherlands, 2005-10. Population Studies, 67(2), 225-241.

Winkelmann, L., \& Winkelmann, R. (1998). Why Are the Unemployed So Unhappy? Evidence from Panel Data. Economica, 65(257), 1-15.

Zimmermann, K. F. (1996). European Migration: Push and Pull. International Regional Science Review, 19(1-2), 95-128. 


\section{Appendix}

Table A.1. Analysis Sample, Matching with Those Planning to Move, Source and Destination

Countries

\begin{tabular}{lcc|lcc}
\hline Birth Country & Freq. & Percent & Residence Country & Freq. & Percent \\
\hline Romania & 13 & 24.530 & Italy & 10 & 18.870 \\
Poland & 8 & 15.090 & Germany & 9 & 16.980 \\
Bulgaria & 4 & 7.550 & Austria & 7 & 13.210 \\
Croatia & 4 & 7.550 & Spain & 5 & 9.430 \\
Estonia & 3 & 5.660 & Greece & 5 & 9.430 \\
Lithuania & 3 & 5.660 & Finland & 3 & 5.660 \\
Kosovo & 3 & 5.660 & France & 2 & 3.770 \\
Czech Republic & 2 & 3.770 & Sweden & 2 & 3.770 \\
Russia & 2 & 3.770 & Australia & 2 & 3.770 \\
Albania & 2 & 3.770 & Ireland & 2 & 3.770 \\
Serbia & 2 & 3.770 & Switzerland & 2 & 3.770 \\
Hungary & 1 & 1.890 & Netherlands & 1 & 1.890 \\
Georgia & 1 & 1.890 & Denmark & 1 & 1.890 \\
Moldova & 1 & 1.890 & Canada & 1 & 1.890 \\
Bosnia and Herzegovina & 1 & 1.890 & New Zealand & 1 & 1.890 \\
Macedonia & 1 & 1.890 & & & \\
Slovakia & 1 & 1.890 & & & \\
Slovenia & 1 & 1.890 & & $\mathbf{5 3}$ & $\mathbf{1 0 0 . 0 0 0}$ \\
\hline Total & $\mathbf{5 3}$ & $\mathbf{1 0 0 . 0 0 0}$ & Total & & \\
\hline SOurce: Authonnny
\end{tabular}

Source: Authors' calculations based on the Gallup World Poll, 2009-2013. 
Table A.2. Summary Statistics, Analysis Sample, Matching with Those Planning to Move

\begin{tabular}{|c|c|c|c|c|c|c|c|c|}
\hline \multirow[b]{2}{*}{ Variables } & \multicolumn{2}{|c|}{ Migrants After } & \multicolumn{2}{|c|}{ Migrants Before } & \multicolumn{2}{|c|}{ Stayers After } & \multicolumn{2}{|c|}{ Stayers Before } \\
\hline & Mean & Std. Dev. & Mean & $\begin{array}{l}\text { Std. } \\
\text { Dev. }\end{array}$ & Mean & Std. Dev. & Mean & $\begin{array}{l}\text { Std. } \\
\text { Dev. }\end{array}$ \\
\hline \multicolumn{9}{|l|}{ Outcome Variables } \\
\hline Household Income (in 1,000 ID) & 39.358 & 32.295 & 15.950 & 25.566 & 14.093 & 11.720 & 15.855 & 12.986 \\
\hline Household Income Per Household Member (in 1,000 ID) & 18.052 & 14.136 & 7.499 & 8.436 & 6.777 & 6.792 & 6.898 & 5.752 \\
\hline Best Possible Life (BPL) (1-10) & 6.245 & 1.890 & 5.981 & 2.414 & 5.981 & 2.374 & 5.302 & 2.180 \\
\hline Satisfaction with Freedom & 0.717 & 0.455 & 0.585 & 0.497 & 0.698 & 0.463 & 0.698 & 0.463 \\
\hline \multicolumn{9}{|l|}{ Matching Variables } \\
\hline Age & 42.943 & 13.226 & 32.547 & 10.451 & 43.491 & 15.298 & 35.736 & 11.746 \\
\hline Female (1=Yes) & 0.660 & 0.478 & 0.660 & 0.478 & 0.660 & 0.478 & 0.660 & 0.478 \\
\hline Catholic (1=Yes) & 0.340 & 0.478 & 0.340 & 0.478 & 0.340 & 0.478 & 0.340 & 0.478 \\
\hline Protestant $(1=$ Yes $)$ & 0.075 & 0.267 & 0.075 & 0.267 & 0.075 & 0.267 & 0.075 & 0.267 \\
\hline Orthodox (1=Yes) & 0.472 & 0.504 & 0.472 & 0.504 & 0.472 & 0.504 & 0.472 & 0.504 \\
\hline Muslim (1=Yes) & 0.075 & 0.267 & 0.075 & 0.267 & 0.075 & 0.267 & 0.075 & 0.267 \\
\hline No religion/Agnostic (1=Yes) & 0.038 & 0.192 & 0.038 & 0.192 & 0.038 & 0.192 & 0.038 & 0.192 \\
\hline Elementary Education (1=Yes) & 0.038 & 0.192 & 0.038 & 0.192 & 0.038 & 0.192 & 0.038 & 0.192 \\
\hline Completed Secondary Education (1=Yes) & 0.660 & 0.478 & 0.660 & 0.478 & 0.660 & 0.478 & 0.660 & 0.478 \\
\hline Some College Education/College Graduate (1=Yes) & 0.302 & 0.463 & 0.302 & 0.463 & 0.302 & 0.463 & 0.302 & 0.463 \\
\hline
\end{tabular}

Source: Authors' calculations based on the Gallup World Poll, 2009-2013.

Notes: The number of observations in each group is 53. All statistics are for 2009-2013 and show the number of observations, means, and standard deviations for each variable and for each migrant and non-migrant group. The means of the binary variables show the proportion of respondents in each category. Household income is in $1,000 \mathrm{~s}$ of international dollars (ID), which allows comparisons across countries and time. The variable "Household Income Per Household Member" is constructed by dividing total household income (in 1,000s ID) by the number of household members. 
Table A.3. EU Analysis Sample, Source and Destination Countries

\begin{tabular}{lcc|lcc}
\hline Birth Country & Freq. & Percent & Residence Country & Freq. & Percent \\
\hline Poland & 26 & 32.910 & Germany & 21 & 26.580 \\
Romania & 25 & 31.650 & Spain & 15 & 18.990 \\
Lithuania & 9 & 11.390 & Ireland & 12 & 15.190 \\
Hungary & 6 & 7.590 & Italy & 10 & 12.660 \\
Slovenia & 6 & 7.590 & Austria & 10 & 12.660 \\
Bulgaria & 4 & 5.060 & Greece & 3 & 3.800 \\
Czech Republic & 1 & 1.270 & France & 2 & 2.530 \\
Estonia & 1 & 1.270 & Sweden & 2 & 2.530 \\
Latvia & 1 & 1.270 & Denmark & 2 & 2.530 \\
& & & Belgium & 1 & 1.270 \\
& \multicolumn{7}{l}{} & $\mathbf{7 9}$ & Finland & 1 & 1.270 \\
\hline \multicolumn{7}{l}{ Total } & $\mathbf{1 0 0 . 0 0 0}$ & Total & $\mathbf{7 9}$ & $\mathbf{1 0 0 . 0 0 0}$ \\
\hline
\end{tabular}


Table A.4. Summary Statistics, EU Analysis Sample

\begin{tabular}{|c|c|c|c|c|c|c|c|c|}
\hline \multirow[b]{2}{*}{ Variables } & \multicolumn{2}{|c|}{$\begin{array}{l}\text { Migrants After } \\
\text { Group } 1\end{array}$} & \multicolumn{2}{|c|}{$\begin{array}{c}\text { Migrants Before } \\
\text { Group } 2\end{array}$} & \multicolumn{2}{|c|}{$\begin{array}{l}\text { Stayers After } \\
\text { Group } 3\end{array}$} & \multicolumn{2}{|c|}{$\begin{array}{l}\text { Stayers Before } \\
\text { Group } 4\end{array}$} \\
\hline & Mean & Std. Dev. & Mean & Std. Dev. & Mean & Std. Dev. & Mean & Std. Dev. \\
\hline \multicolumn{9}{|l|}{ Outcome Variables } \\
\hline Household Income (in 1,000 s ID) & 31.337 & 26.658 & 14.578 & 16.114 & 14.573 & 9.625 & 15.706 & 18.609 \\
\hline HH Income Per HH Member (in 1,000s ID) & 16.139 & 15.574 & 5.902 & 5.995 & 6.250 & 3.820 & 7.319 & 7.090 \\
\hline Best Possible Life (BPL) (1-10) & 6.405 & 1.971 & 4.848 & 2.248 & 5.557 & 2.459 & 5.797 & 2.127 \\
\hline Satisfaction with Freedom & 0.886 & 0.320 & 0.595 & 0.494 & 0.671 & 0.473 & 0.658 & 0.477 \\
\hline \multicolumn{9}{|l|}{ Matching Variables } \\
\hline Age & 41.937 & 12.504 & 40.139 & 13.068 & 43.241 & 11.340 & 40.848 & 12.356 \\
\hline Female $(1=$ Yes $)$ & 0.557 & 0.500 & 0.557 & 0.500 & 0.557 & 0.500 & 0.557 & 0.500 \\
\hline Catholic (1=Yes) & 0.582 & 0.496 & 0.582 & 0.496 & 0.582 & 0.496 & 0.582 & 0.496 \\
\hline Protestant $(1=$ Yes $)$ & 0.025 & 0.158 & 0.025 & 0.158 & 0.025 & 0.158 & 0.025 & 0.158 \\
\hline Orthodox $(1=$ Yes $)$ & 0.354 & 0.481 & 0.354 & 0.481 & 0.354 & 0.481 & 0.354 & 0.481 \\
\hline No religion/Agnostic ( $1=$ Yes) & 0.038 & 0.192 & 0.038 & 0.192 & 0.038 & 0.192 & 0.038 & 0.192 \\
\hline Elementary Education ( $1=$ Yes) & 0.089 & 0.286 & 0.089 & 0.286 & 0.089 & 0.286 & 0.089 & 0.286 \\
\hline Completed Secondary Education $(1=$ Yes $)$ & 0.747 & 0.438 & 0.747 & 0.438 & 0.747 & 0.438 & 0.747 & 0.438 \\
\hline Some College Education/ & & & & & & & & \\
\hline College Graduate (1=Yes) & 0.165 & 0.373 & 0.165 & 0.373 & 0.165 & 0.373 & 0.165 & 0.373 \\
\hline
\end{tabular}

Source: Authors' calculations based on the Gallup World Poll, 2009-2013.

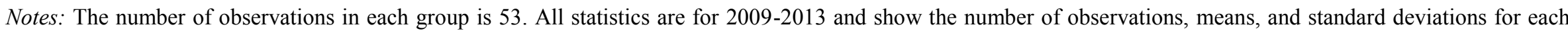

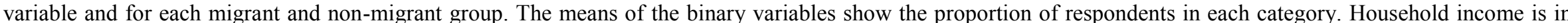

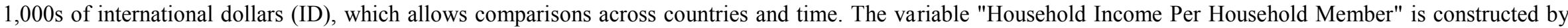
dividing total household income (in 1,000s ID) by the number of household members. 
Table A.5. Balancing Tests, Return Migration Matching, Nearest Neighbor Matching Without Replacement, Caliper $=0.01$

\begin{tabular}{|c|c|c|c|c|c|}
\hline \multirow[b]{2}{*}{ Variable } & \multicolumn{2}{|c|}{ Mean } & \multirow[b]{2}{*}{$\%$ Bias } & \multirow[b]{2}{*}{ t-stat } & \multirow[b]{2}{*}{ p-value } \\
\hline & Treated & Control & & & \\
\hline Age & 43.083 & 43.325 & -1.400 & -0.170 & 0.869 \\
\hline Age Squared & 2150.000 & 2119.900 & 1.800 & 0.210 & 0.832 \\
\hline Female & 0.683 & 0.635 & 9.700 & 1.130 & 0.260 \\
\hline Elementary Education & 0.075 & 0.083 & -2.800 & -0.330 & 0.742 \\
\hline $\begin{array}{l}\text { Completed Secondary Education } \\
\text { Some College Education/College }\end{array}$ & 0.575 & 0.579 & -0.800 & -0.090 & 0.928 \\
\hline Graduate & 0.349 & 0.337 & 2.600 & 0.280 & 0.779 \\
\hline Poland & 0.048 & 0.048 & 0.000 & 0.000 & 1.000 \\
\hline Hungary & 0.012 & 0.012 & 0.000 & 0.000 & 1.000 \\
\hline Czech Republic & 0.028 & 0.028 & 0.000 & 0.000 & 1.000 \\
\hline Romania & 0.052 & 0.052 & 0.000 & 0.000 & 1.000 \\
\hline Belarus & 0.008 & 0.008 & 0.000 & 0.000 & 1.000 \\
\hline Georgia & 0.067 & 0.067 & 0.000 & 0.000 & 1.000 \\
\hline Kazakhstan & 0.040 & 0.040 & 0.000 & 0.000 & 1.000 \\
\hline Kyrgyzstan & 0.008 & 0.008 & 0.000 & 0.000 & 1.000 \\
\hline Moldova & 0.063 & 0.063 & 0.000 & 0.000 & 1.000 \\
\hline Russia & 0.282 & 0.282 & 0.000 & 0.000 & 1.000 \\
\hline Ukraine & 0.063 & 0.063 & 0.000 & 0.000 & 1.000 \\
\hline Albania & 0.111 & 0.111 & 0.000 & 0.000 & 1.000 \\
\hline Armenia & 0.028 & 0.028 & 0.000 & 0.000 & 1.000 \\
\hline Bosnia and Herzegovina & 0.028 & 0.028 & 0.000 & 0.000 & 1.000 \\
\hline Bulgaria & 0.044 & 0.044 & 0.000 & 0.000 & 1.000 \\
\hline Croatia & 0.012 & 0.012 & 0.000 & 0.000 & 1.000 \\
\hline Estonia & 0.024 & 0.024 & 0.000 & 0.000 & 1.000 \\
\hline Latvia & 0.012 & 0.012 & 0.000 & 0.000 & 1.000 \\
\hline Lithuania & 0.016 & 0.016 & 0.000 & 0.000 & 1.000 \\
\hline Macedonia & 0.016 & 0.016 & 0.000 & 0.000 & 1.000 \\
\hline Serbia & 0.020 & 0.020 & 0.000 & 0.000 & 1.000 \\
\hline Slovakia & 0.008 & 0.008 & 0.000 & 0.000 & 1.000 \\
\hline $\begin{array}{l}\text { Slovenia } \\
\text { Uzbekistan }\end{array}$ & $\begin{array}{l}0.004 \\
0.008\end{array}$ & $\begin{array}{l}0.004 \\
0.008\end{array}$ & $\begin{array}{l}0.000 \\
0.000\end{array}$ & $\begin{array}{l}0.000 \\
0.000\end{array}$ & $\begin{array}{l}1.000 \\
1.000\end{array}$ \\
\hline Catholic & 0.190 & 0.187 & 1.100 & 0.110 & 0.910 \\
\hline Protestant & 0.135 & 0.083 & 17.200 & 1.860 & 0.063 \\
\hline Christianity: Orthodox & 0.393 & 0.488 & -20.600 & -2.160 & 0.031 \\
\hline Islam/Muslim & 0.111 & 0.095 & 4.600 & 0.580 & 0.559 \\
\hline Judaism & 0.008 & 0.008 & 0.000 & 0.000 & 1.000 \\
\hline No Religion/Agnostic & 0.147 & 0.111 & 14.400 & 1.200 & 0.232 \\
\hline Christian & 0.016 & 0.028 & -6.900 & -0.910 & 0.361 \\
\hline Year 2009 & 0.111 & 0.111 & 0.000 & 0.000 & 1.000 \\
\hline Year 2010 & 0.143 & 0.143 & 0.000 & 0.000 & 1.000 \\
\hline Year 2011 & 0.587 & 0.587 & 0.000 & 0.000 & 1.000 \\
\hline Year 2012 & 0.159 & 0.159 & 0.000 & 0.000 & 1.000 \\
\hline Mean Bias & $\begin{array}{l}\text { Before } \\
\text { After }\end{array}$ & $\begin{array}{c}21.488 \\
1.680 \\
\end{array}$ & & & \\
\hline
\end{tabular}


Table A.6. Balancing Tests, Return Migration Matching, Nearest Neighbor Matching Without Replacement, Caliper $=0.0001$

\begin{tabular}{|c|c|c|c|c|c|}
\hline \multirow[b]{2}{*}{ Variable } & \multicolumn{2}{|c|}{ Mean } & \multirow[b]{2}{*}{$\%$ Bias } & \multirow[b]{2}{*}{ t-stat } & \multirow[b]{2}{*}{ p-value } \\
\hline & Treated & Control & & & \\
\hline Age & 40.711 & 40.474 & 1.400 & 0.100 & 0.921 \\
\hline Age Squared & 1884.000 & 1842.600 & 2.500 & 0.180 & 0.854 \\
\hline Female & 0.711 & 0.684 & 5.300 & 0.350 & 0.726 \\
\hline Elementary Education & 0.053 & 0.053 & 0.000 & 0.000 & 1.000 \\
\hline Completed Secondary Education & 0.632 & 0.632 & 0.000 & 0.000 & 1.000 \\
\hline Some College Education/College Graduate & 0.316 & 0.316 & 0.000 & 0.000 & 1.000 \\
\hline Poland & 0.053 & 0.053 & 0.000 & 0.000 & 1.000 \\
\hline Romania & 0.026 & 0.026 & 0.000 & 0.000 & 1.000 \\
\hline Georgia & 0.132 & 0.132 & 0.000 & 0.000 & 1.000 \\
\hline Kazakhstan & 0.013 & 0.013 & 0.000 & 0.000 & 1.000 \\
\hline Kyrgyzstan & 0.013 & 0.013 & 0.000 & 0.000 & 1.000 \\
\hline Moldova & 0.066 & 0.066 & 0.000 & 0.000 & 1.000 \\
\hline Russia & 0.368 & 0.368 & 0.000 & 0.000 & 1.000 \\
\hline Ukraine & 0.053 & 0.053 & 0.000 & 0.000 & 1.000 \\
\hline Albania & 0.039 & 0.039 & 0.000 & 0.000 & 1.000 \\
\hline Armenia & 0.079 & 0.079 & 0.000 & 0.000 & 1.000 \\
\hline Bosnia and Herzegovina & 0.039 & 0.039 & 0.000 & 0.000 & 1.000 \\
\hline Bulgaria & 0.013 & 0.013 & 0.000 & 0.000 & 1.000 \\
\hline Estonia & 0.026 & 0.026 & 0.000 & 0.000 & 1.000 \\
\hline Latvia & 0.039 & 0.039 & 0.000 & 0.000 & 1.000 \\
\hline Lithuania & 0.026 & 0.026 & 0.000 & 0.000 & 1.000 \\
\hline Slovenia & 0.013 & 0.013 & 0.000 & 0.000 & 1.000 \\
\hline Religion: Other & 0.013 & 0.000 & 29.500 & 1.000 & 0.319 \\
\hline Catholic & 0.105 & 0.118 & -3.800 & -0.260 & 0.799 \\
\hline Protestant & 0.079 & 0.079 & 0.000 & 0.000 & 1.000 \\
\hline Christianity: Orthodox & 0.579 & 0.658 & -17.100 & -1.000 & 0.320 \\
\hline Islam/Muslim & 0.079 & 0.079 & 0.000 & 0.000 & 1.000 \\
\hline Buddhism & 0.013 & 0.000 & 52.500 & 1.000 & 0.319 \\
\hline Judaism & 0.013 & 0.013 & 0.000 & 0.000 & 1.000 \\
\hline No Religion/Agnostic & 0.066 & 0.039 & 10.600 & 0.720 & 0.471 \\
\hline Christian & 0.053 & 0.013 & 22.900 & 1.360 & 0.175 \\
\hline Year 2009 & 0.066 & 0.066 & 0.000 & 0.000 & 1.000 \\
\hline Year 2010 & 0.158 & 0.158 & 0.000 & 0.000 & 1.000 \\
\hline Year 2011 & 0.618 & 0.618 & 0.000 & 0.000 & 1.000 \\
\hline Year 2012 & 0.158 & 0.158 & 0.000 & 0.000 & 1.000 \\
\hline Mean Bias & $\begin{array}{l}\text { Before } \\
\text { After }\end{array}$ & $\begin{array}{c}21.488 \\
2.912\end{array}$ & & & \\
\hline
\end{tabular}


Table A.7. Balancing Tests, Return Migration Matching, Nearest Neighbor Matching Without Replacement, Caliper $=0.01$

\begin{tabular}{lccccc}
\hline & \multicolumn{2}{c}{ Mean } & & & \\
Variable & Treated & Control & \% Bias & t-stat & p-value \\
\hline Age & 38.310 & 38.238 & 0.500 & 0.030 & 0.979 \\
Age Squared & 1629.100 & 1600.500 & 2.100 & 0.130 & 0.899 \\
Female & 0.405 & 0.429 & -5.000 & -0.220 & 0.827 \\
Elementary Education & 0.000 & 0.024 & -15.700 & -1.000 & 0.320 \\
Completed Secondary Education & 0.738 & 0.810 & -15.300 & -0.780 & 0.440 \\
Some College Education/College & & & & & \\
Graduate & 0.262 & 0.167 & 20.700 & 1.060 & 0.293 \\
Georgia & 0.286 & 0.286 & 0.000 & 0.000 & 1.000 \\
Kyrgyzstan & 0.095 & 0.095 & 0.000 & 0.000 & 1.000 \\
Russia & 0.286 & 0.286 & 0.000 & 0.000 & 1.000 \\
Ukraine & 0.214 & 0.214 & 0.000 & 0.000 & 1.000 \\
Armenia & 0.048 & 0.048 & 0.000 & 0.000 & 1.000 \\
Azerbaijan & 0.071 & 0.071 & 0.000 & 0.000 & 1.000 \\
\hline Mean Bias & Before & $\mathbf{4 6 . 5 9 7}$ & & & \\
& After & $\mathbf{3 . 4 8 8}$ & & & \\
\hline
\end{tabular}

